Article

\title{
The Proteasome Inhibitor Bortezomib Sensitizes AML with Myelomonocytic Differentiation to TRAIL Mediated Apoptosis
}

\author{
Marianne van Dijk ${ }^{1,2}$, Eoin Murphy ${ }^{1,2}$, Ruth Morrell ${ }^{1,2,3}$, Steven Knapper ${ }^{4}$, Michael O’Dwyer ${ }^{1,3}$, \\ Afshin Samali ${ }^{1,2}$ and Eva Szegezdi ${ }^{1,2, *}$
}

1 Apoptosis Research Center, National University of Ireland, University Road, Galway, Ireland; E-Mails: m.vandijk1@ nuigalway.ie (M.V.D); Eoin.murphy@nuigalway.ie (E.M); ruth.morrell@ nuigalway.ie (R.M); afshin.samali@ nuigalway.ie (A.S); michael.odwyer@ hse.ie (M.O.)

2 School of Natural Sciences, National University of Ireland, University Road, Galway, Ireland

3 School of Medicine, National University of Ireland, University Road, Galway, Ireland

4 Department of Haematology, School of Medicine, Cardiff University, Heath Park, CF14 4XN Cardiff, UK; E-Mail: KnapperS@cf.ac.uk

* Author to whom correspondence should be addressed; E-Mail: eva.szegezdi@nuigalway.ie; Tel.: +353-91-495037; Fax: +353-91-494-596.

Received: 5 February 2011; in revised form: 15 February 2011 / Accepted: 10 March 2011 / Published: 15 March 2011

\begin{abstract}
Acute myeloid leukemia (AML) is an aggressive stem cell malignancy that is difficult to treat. There are limitations to the current treatment regimes especially after disease relapse, and therefore new therapeutic agents are urgently required which can overcome drug resistance whilst avoiding unnecessary toxicity. Among newer targeted agents, both tumor necrosis factor (TNF)-related apoptosis-inducing ligand (TRAIL) and proteasome inhibitors show particular promise. In this report we show that a combination of the proteasome inhibitor bortezomib and TRAIL is effective against AML cell lines, in particular, AML cell lines displaying myelomonocytic/monocytic phenotype (M4/M5 AML based on FAB classification), which account for 20-30\% of AML cases. We show that the underlying mechanism of sensitization is at least in part due to bortezomib mediated downregulation of c-FLIP and XIAP, which is likely to be regulated by NF- $\mathrm{BB}$. Blockage of NF- $\mathrm{BB}$ activation with BMS-345541 equally sensitized myelomonocytic AML cell lines and primary AML blasts to TRAIL.
\end{abstract}

Keywords: AML; FAB M4/M5; TRAIL; bortezomib; apoptosis; NF-кB; c-FLIP 


\section{Introduction}

Acute myeloid leukemia (AML) is an aggressive stem cell malignancy characterized by proliferation and accumulation of immature hematopoietic cells in the bone marrow and peripheral blood, leading to the clinical manifestations of bone marrow failure. With standard anthracycline and cytarabine based induction chemotherapy, complete remission (CR) is achieved in 50-80\% of patients considered suitable for intensive treatment [1]. However, despite achievement of CR and subsequent post-remission therapy, the majority of patients relapse and die of their disease [1]. Moreover, many older patients are not deemed suitable for intensive therapy due to excessive treatment related mortality. The optimal treatment for these older patients has not been defined. Thus, overall five-year survival in adults remains less than $50 \%$ in patients under 45 years of age and $<5 \%$ in patients over 65 years at diagnosis [2]. The poor survival in older patients is particularly important given that the majority of patients belong to this age group.

Relapse of AML following chemotherapy is likely due to the persistence of resistant leukemic cells localized within the bone marrow [2]. This resistance may be attributed to intrinsic properties of the leukemic stem or progenitor cells, as well as to their interaction with the bone marrow microenvironment. Due to the limitations of current regimes, new chemotherapeutic agents are urgently required, which can overcome drug resistance whilst avoiding unnecessary toxicity. Among the newer targeted agents, both tumor necrosis factor (TNF)-related apoptosis-inducing ligand (TRAIL) and proteasome inhibitors show particular promise [3].

A major challenge in the treatment of all malignancies remains the destruction of cancer cells whilst sparing normal cells. TRAIL is a type II transmembrane protein with the ability to promote apoptosis, in a p53-independent manner, by engaging the death receptors DR4 and DR5 while sparing most normal cells [4]. It is active in a variety of tumor cell lines and xenotransplant mouse models thus making it a promising anti-cancer cytokine [5-7]. However, many primary tumors, including AML, are resistant to the pro-apoptotic effects of recombinant human TRAIL (rhTRAIL) through a variety of mechanisms including reduced expression of DR4/DR5, elevated expression of TRAIL decoy receptors [8] and increased expression of anti-apoptotic proteins such as cellular-FLICE-inhibitory protein (c-FLIP) and X-linked inhibitor of apoptosis protein (XIAP) [9-11]. As a consequence, stimulation of the death receptors results in alternative signaling with activation and nuclear translocation of nuclear factor- $\kappa \mathrm{B}(\mathrm{NF}-\kappa \mathrm{B})$, which, in turn, leads to the induction of anti-apoptotic and prosurvival genes further increasing resistance [12].

In an attempt to bypass this resistance, various anti-tumor agents have been combined with rhTRAIL to study their sensitizing effects. Of increasing interest is the combination of rhTRAIL with proteasome inhibitors, such as bortezomib, a highly selective, reversible inhibitor of the chymotrypsinlike activity of the proteasome complex [13-15]. The 26S proteasome is a large intracellular multisubunit protease (1500-2000 kDa) that consists of one $20 \mathrm{~S}$ catalytic core complex associated with $19 \mathrm{~S}$ or $11 \mathrm{~S}$ regulatory complexes. It has three distinct catalytic properties, namely a trypsin-like, a chymotrypsin-like and a peptidyl-glutamyl peptide hydrolyzing activities [16-18]. The ubiquitinproteasome system (UPS) mediates the degradation of polyubiquitinated proteins and represents one of the main pathways of protein degradation in eukaryotic cells. The pronounced apoptosis-inducing activity of bortezomib has been demonstrated in many types of cancer $[19,20]$. Proposed mechanisms 
include (i) intracellular accumulation of $\mathrm{p} 53$, the $\mathrm{I} \kappa \mathrm{B} / \mathrm{NF}-\kappa \mathrm{B}$ complex leading to NF- $\kappa \mathrm{B}$ inhibition and pro-apoptotic members of the Bcl-2 family [19,21] and (ii) altered cell cycle regulation through stabilization of cyclins and the CDK inhibitors p21 and p27 [22].

AML cells display varying in vitro sensitivity to apoptosis induced by proteasome inhibitors $[8,23]$. Studies have shown that human leukemic cells express abnormally high levels of proteasomes, compared with their normal counterparts [24] and that activity patterns of the various subunits varies in primary leukemia cells, which reflects their sensitivity to bortezomib [25]. In addition, many cases of AML show increased activation of the survival-signaling pathway mediated by NF- $\kappa \mathrm{B}$ [26], particularly the leukemic stem cell component, and importantly, it has been shown that leukemic stem cells are more susceptible to bortezomib-induced apoptosis than their normal counterparts [27]. In the clinical setting, however, bortezomib has limited single agent activity possibly due to its relatively low maximum tolerated dose [28]. Combination approaches have higher potential with a promising CR rate being achieved in a high-risk cohort of patients when bortezomib was combined with standard AML induction therapy [29]. However, as most elderly patients with AML do not tolerate intensive induction chemotherapy, investigation of other novel combinations is needed.

The combination of rhTRAIL and bortezomib has shown synergistic apoptotic responses in a variety of malignancies including chronic lymphocytic leukemia and AML [8,30], non-small cell lung cancer [31] and non-Hodgkin's lymphoma [32]. Although the precise molecular mechanisms are unclear, in many instances the stimulatory effects of bortezomib on TRAIL receptor DR4/DR5 expression and the downmodulation of c-FLIP seem to be key mediators in the enhancement process [33], although this may be cell-type specific. Sensitised tumor cells may also demonstrate stronger DISC formation, with increased FADD and caspase-8 recruitment [34]. Finally, blockage of TRAIL-induced NF- $\mathrm{B}$ activation by bortezomib may also play a role [32].

In the present work, we explored the sensitivity of several AML cell lines to rhTRAIL and the proteasome inhibitor, bortezomib. In addition, we evaluated the ability of bortezomib to co-operate with rhTRAIL as well as exploring the mechanism underlying their co-operation. The results indicate that, particularly in cell lines of myelomonocytic differentiation, pre-treatment with bortezomib enhances rhTRAIL-induced apoptotic signaling both in rhTRAIL-sensitive and TRAIL-resistant cell lines. We demonstrate that the inhibition of NF- $\kappa \mathrm{B}$ activation plays a central role in sensitizing AML to rhTRAIL-induced apoptosis. In addition, treatment with bortezomib caused a downregulation of c-FLIP and in specific cell lines, XIAP, further strengthening the importance of NF- $\kappa$ B inhibition as a molecular basis to explain sensitization of myelomonocytic AML cells to rhTRAIL.

\section{Results and Discussion}

\subsection{AML Cell Lines Show Varied Resistance to TRAIL}

To investigate the effect of rhTRAIL on the growth and survival of AML cells, a panel of AML cell lines was chosen representing different stages of differentiation. KG-1 cells are phenotypically characterized as immature or minimally differentiated-FAB (French-American-British) classification M0, Kasumi as FAB M2, HL-60 as promyelocytic (M3) and the remaining cell lines ML-1, ML-2, OCI AML2, OCI AML3 as myelomonocytic (M4) or monocytic (M5a: MOLM13). Cells were treated 
with increasing concentrations of rhTRAIL (10 to $1000 \mathrm{ng} / \mathrm{mL}$ ) for $24 \mathrm{~h}$. Following treatment, cell viability was measured by MTT assay.

The cell lines exhibited variable sensitivities to rhTRAIL. Kasumi, KG-1, OCI AML2 and OCI AML3 were highly resistant showing a cell viability of $>80 \%$ at the highest rhTRAIL concentration, while HL-60, ML-1, ML-2 and MOLM13 cells were more susceptible to the cytotoxic effects of rhTRAIL in a dose dependent manner (Figure 1).

Figure 1. Acute myeloid leukemia (AML) cell lines show varied resistance to rhTRAIL. AML cell lines were treated with 10, 50, 250 or $1000 \mathrm{ng} / \mathrm{mL}$ TRAIL for $24 \mathrm{~h}$. Cell viability was measured by MTT assay; values are expressed as a percent of untreated cells and presented as mean \pm S.E.M.

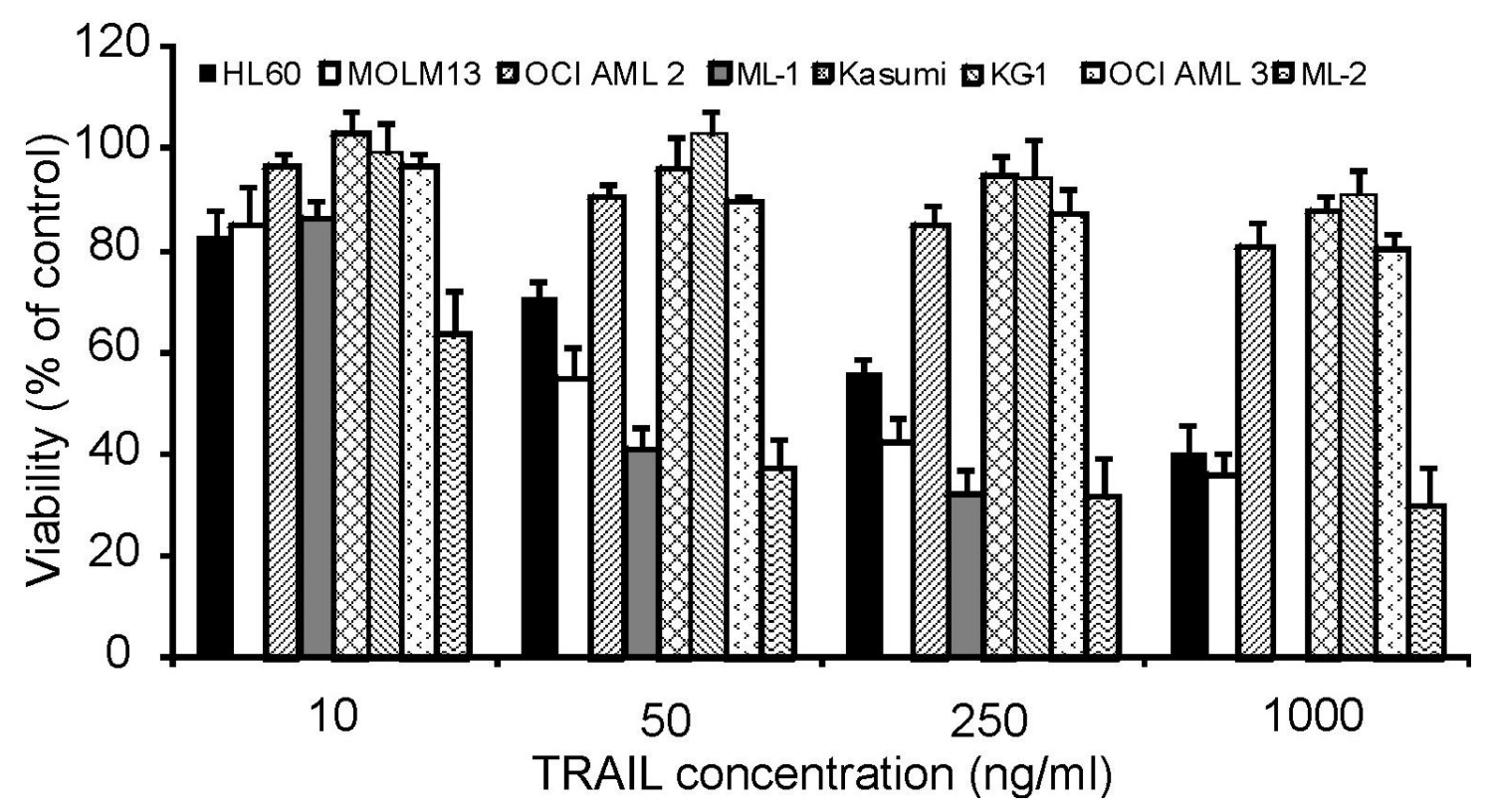

\subsection{AML Cell Lines are Highly Sensitive to Bortezomib}

Bortezomib is a boronic acid dipeptide, which acts as a reversible inhibitor of the $26 \mathrm{~S}$ proteasome. The panel of AML cell lines were treated with increasing concentrations of bortezomib for $24 \mathrm{~h}$ after which cell viability was measured by MTT assay. All cell lines were sensitive to bortezomib; however, the degree of sensitivity varied (Figure 2) with OCI AML3 being the most resistant, requiring a dose of $>25 \mathrm{nM}$ bortezomib to show a 50\% reduction in cell viability (Figure 2). KG-1 and MOLM13 cells exhibited the greatest sensitivity with a reduction in cell viability of approximately $62 \%$ and $37 \%$, respectively, following treatment with $5 \mathrm{nM}$ of bortezomib. In all cases, the effect on cell viability was dose-dependent and reached a plateau. 
Figure 2. AML cell lines are highly sensitive to bortezomib. AML cell lines were treated with $5,10,25$ or $50 \mathrm{nM}$ bortezomib for $24 \mathrm{~h}$ after which cell viability was measured by MTT assay. Values are expressed as a percent of untreated cells and presented as mean \pm S.E.M.

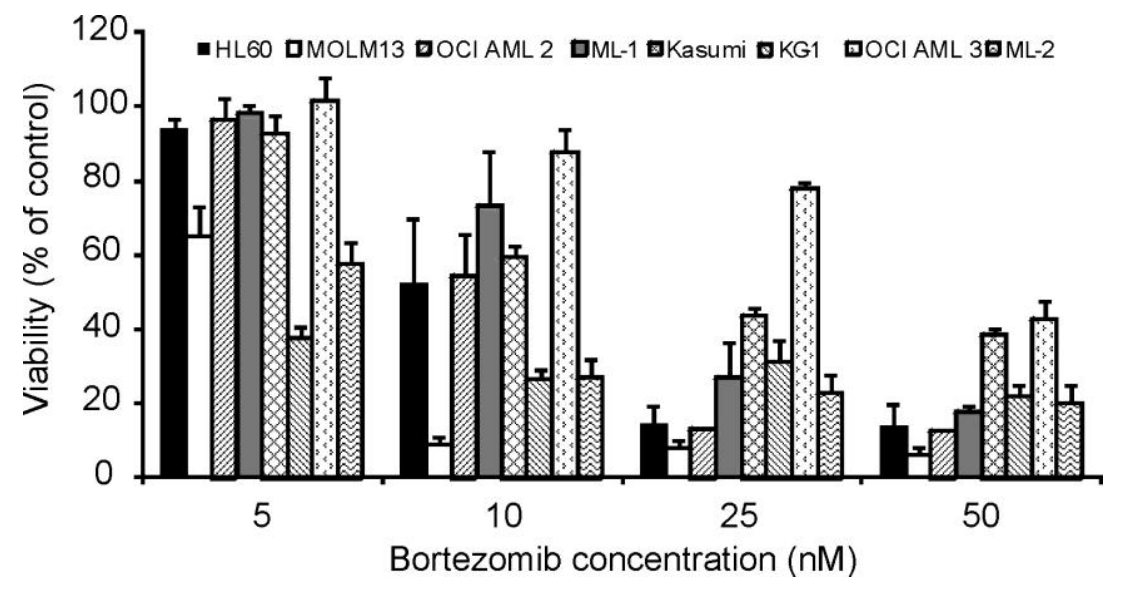

\subsection{Bortezomib Treatment Inhibits the Chymotryptic Activity of the Proteasome in AML Cell Lines}

In order to investigate the degree of inhibition of the proteasome following bortezomib treatment, the three different enzymatic activities of the proteasome, chymotrypsin-like, trypsin-like and peptidylglutamyl-peptidyl hydrolase (PGPH)), were measured in the panel of AML cell lines after 6 and $9 \mathrm{~h}$ of exposure. Using a concentration of $100 \mathrm{nM}$ (previously shown to induce almost complete cell death in all cell lines) bortezomib almost completely inhibited the chymotryptic activity of the proteasome in all cell lines cells after $6 \mathrm{~h}$ of treatment (Figure 3). Tryptic activity was the lowest of the three enzymatic activities and remained unaffected by bortezomib treatment in all cell lines while the PGPH activity was partially inhibited apart from in HL-60, ML-2 and OCI AML2 cells in which PGPH activity was unaffected by bortezomib, however these cell lines did not show higher or lower sensitivity to bortezomib.

\subsection{Degree of Proteasome Inhibition does not Correlate with Bortezomib Sensitivity}

To further study the effect of bortezomib on the chymotryptic activity in AML cell lines, the panel of AML cells were treated with a range of bortezomib concentrations ( $2 \mathrm{nM}$ to $100 \mathrm{nM})$ for $6 \mathrm{~h}$ and the chymotryptic proteasomal activity was measured. The highest basal chymotryptic activity was seen in the MOLM13 and KG-1 cell lines, the two cell lines with the highest bortezomib sensitivity. The cell lines were grouped according to the degree of proteasomal inhibition obtained, with MOLM13, OCI AML2, HL60 and Kasumi cells being the most sensitive ( $\mathrm{IC}_{50}$ value of $1.9 \pm 0.5 \mathrm{nM}$ ), while OCI AML3, KG-1, ML-1 and ML-2 cells were more resistant ( $\mathrm{IC}_{50}$ value of $5.1 \pm 0.4 \mathrm{nM}$ ) requiring approximately 2.5-fold more bortezomib for half-maximal inhibition of the chymotryptic activity of the proteasome (Figure 4). Overall, in all cell lines, a low nanomolar concentration of bortezomib was sufficient to reduce proteasome activity to less than $20 \%$ of the basal activity. However, the sensitivity to proteasomal inhibition does not correlate tightly with the effects of bortezomib on cell viability (Figure 2). For example, KG-1 and MOLM13 are both sensitive to bortezomib in cell viability assays but chymotryptic activity assays show that chymotryptic activity is inhibited at low concentrations of bortezomib in MOLM13, whereas higher concentrations of bortezomib are required to inhibit chymotryptic activity in KG-1. 
Figure 3. Bortezomib inhibits the chymotryptic activity of the proteasome. AML cells were treated with $100 \mathrm{nM}$ bortezomib for 6,9 or $18 \mathrm{~h}$. Chymotryptic-like (CT), tryptic-like (T) and PGPH-like proteasomal activity was measured as described in the experimental section Proteasome activity is expressed as nmoles substrate (AMC) cleaved per $1 \mathrm{mg}$ cellular protein in one minute \pm S.E.M. (A) HL-60; (B) KG-1; (C) Kasumi; (D) OCI AML2; (E) OCI AML3; (F) MOLM13; (G) ML-2; (H) ML-1.

A

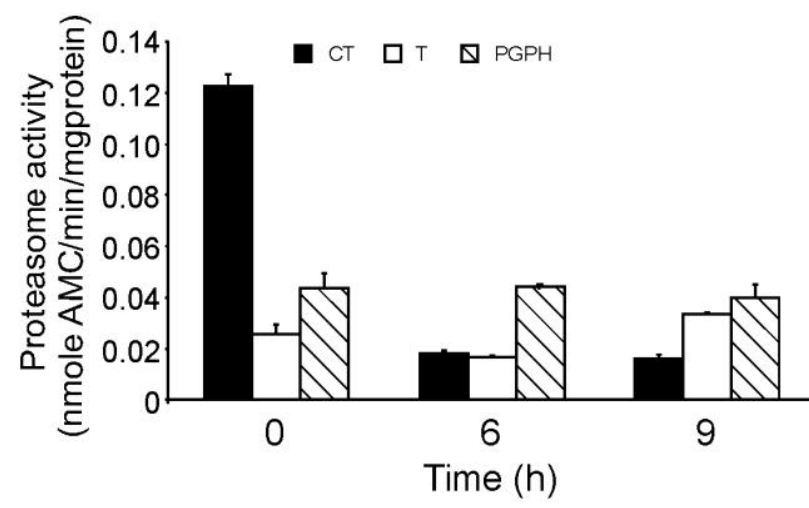

B

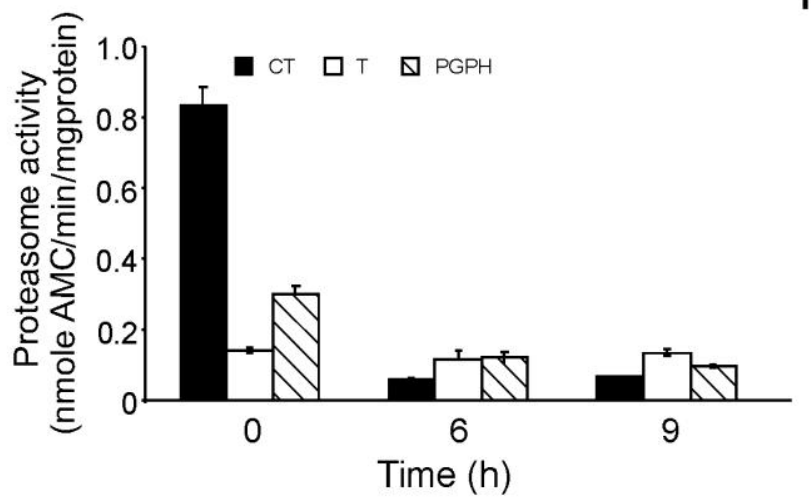

C

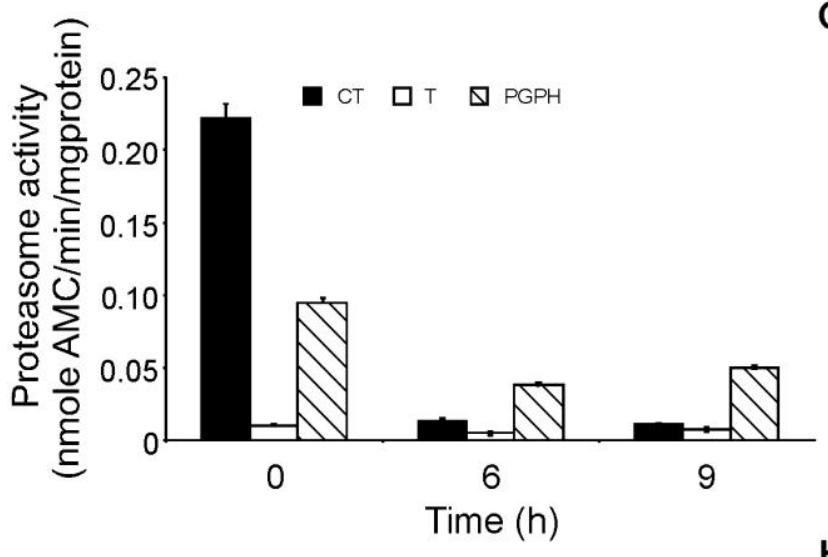

D

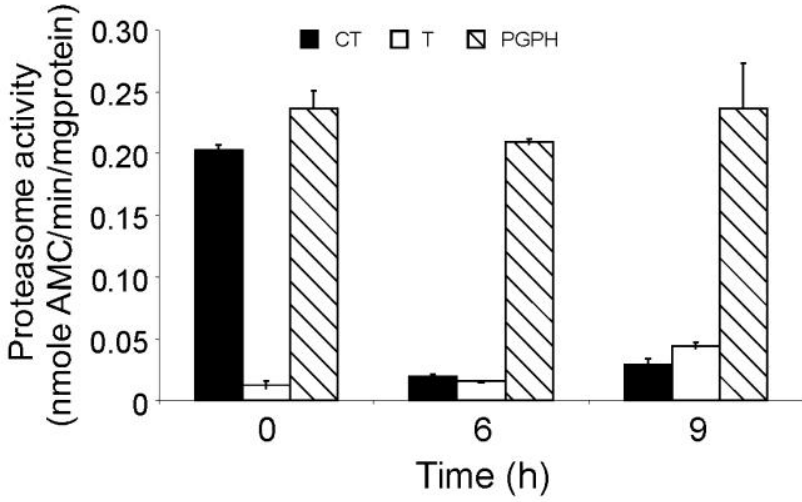

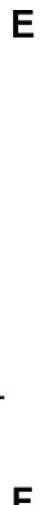
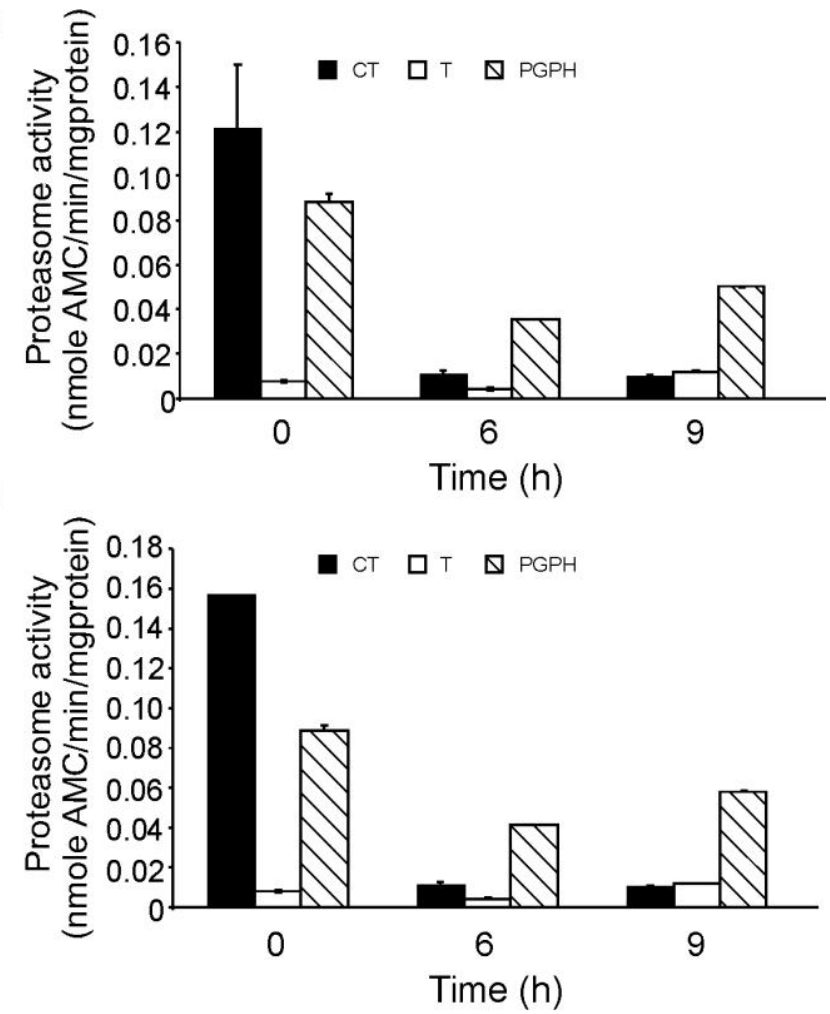

G

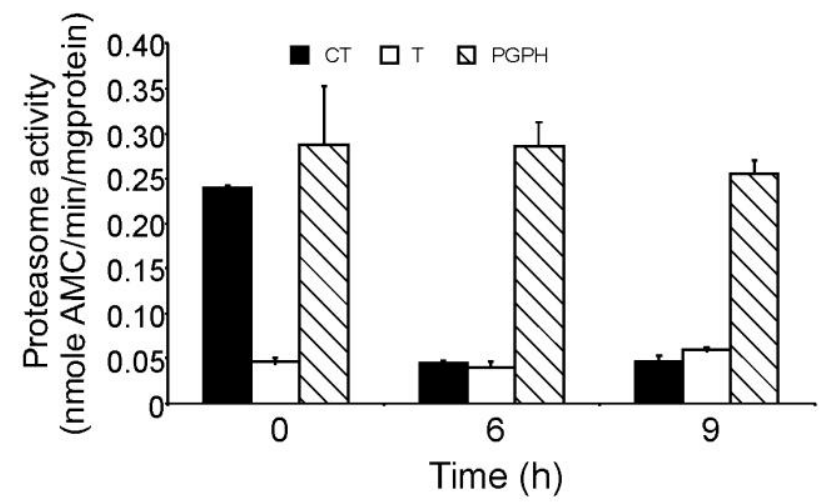

H

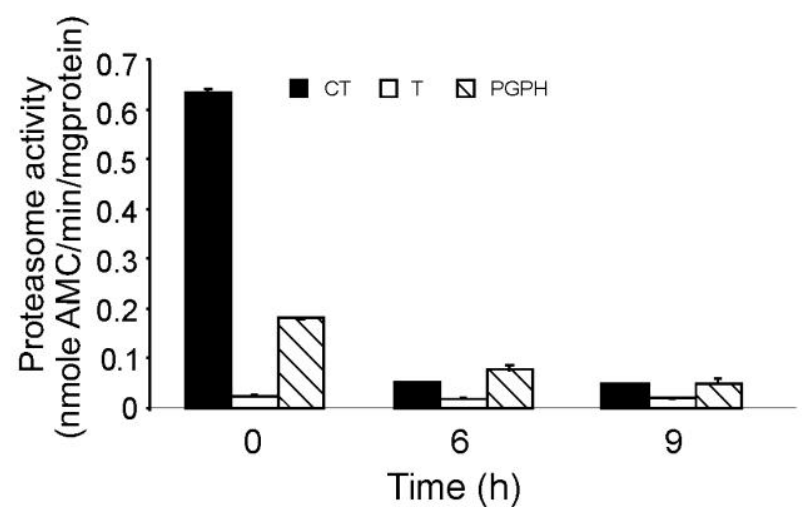


Figure 4. Proteasome inhibition increases with increasing concentration of bortezomib. AML cells were treated with increasing doses of bortezomib $(0-100 \mathrm{nM})$ for $6 \mathrm{~h}$. Proteasome activity is expressed as nmoles substrate (AMC) cleaved per $1 \mathrm{mg}$ cellular protein in one minute \pm S.E.M.
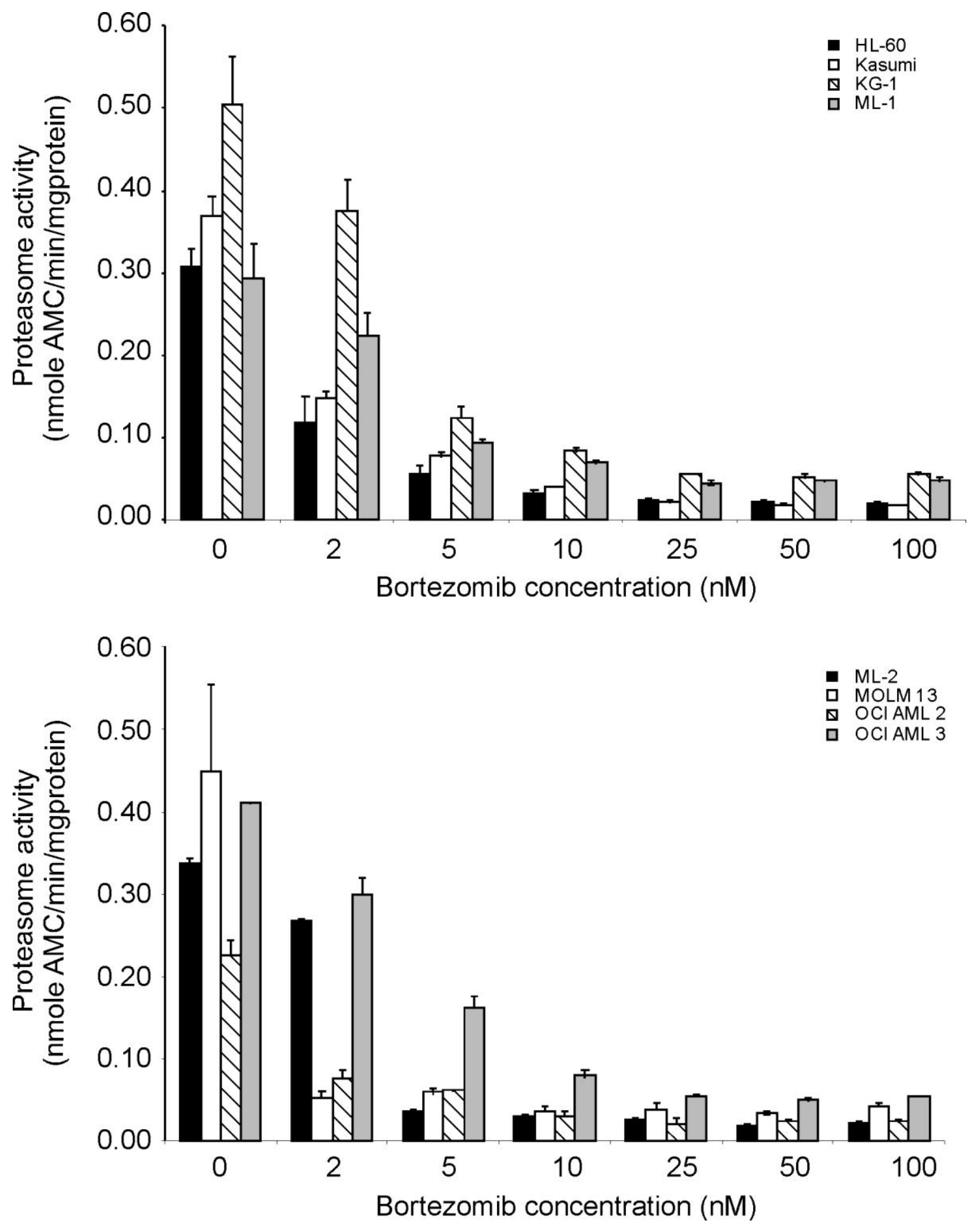


\subsection{Bortezomib Sensitizes Myelomonocytic AML Cells to TRAIL-Induced Apoptosis}

We next evaluated the effect of bortezomib-induced proteasome inhibition in combination with rhTRAIL-mediated death in the panel of AML cell lines. Cells were treated with a concentration of bortezomib that induced approximately $20 \%$ reduction in viability and was sufficient to inhibit the chymotrypsin-like activity of the proteasome. Pre-treatment of cells with bortezomib for $18 \mathrm{~h}$ followed by rhTRAIL treatment for a further $18 \mathrm{~h}$ or $24 \mathrm{~h}$ led to TRAIL sensitization in ML-1, ML-2, OCI AML2, OCI AML3 cells and MOLM13 (Figure 5D, 5E, 5F, 5G, 5H). Interestingly, all of these cell lines are of either myelomonocytic (M4) or monocytic (M5) differentiation. The synergistic action of the two agents was confirmed with a combination index $(\mathrm{CI})<1$ using the Chou-Talalay method (Table 1). Pretreatment with bortezomib did not sensitize HL-60, KG-1 and Kasumi to rhTRAIL-induced apoptosis (Figure 5A, 5B and 5C). Results were confirmed using Annexin V/PI assay (data not shown).

Table 1. CI values of synergistic drug interactions in M4/M5 AML cell lines.

\begin{tabular}{|c|c|c|c|}
\hline \multirow{6}{*}{ ML-1 } & TRAIL (ng/mL) & $\mathbf{B z}(\mathbf{n M})$ & CI \\
\hline & 10.0 & 7.0 & 0.93172 \\
\hline & 25.0 & 7.0 & 0.62343 \\
\hline & 50.0 & 7.0 & 0.51661 \\
\hline & 100.0 & 7.0 & 0.69512 \\
\hline & 250.0 & 7.0 & 1.37954 \\
\hline \multirow{6}{*}{ ML-2 } & TRAIL (ng/mL) & $\mathbf{B z}(\mathbf{n M})$ & CI \\
\hline & 10.0 & 4.0 & 0.12802 \\
\hline & 25.0 & 4.0 & 0.07240 \\
\hline & 50.0 & 4.0 & 0.09342 \\
\hline & 100.0 & 4.0 & 0.18088 \\
\hline & 250.0 & 4.0 & 0.47115 \\
\hline \multirow{6}{*}{ MOLM-13 } & TRAIL (ng/mL) & Bz (nM) & CI \\
\hline & 10.0 & 8.0 & 0.96874 \\
\hline & 25.0 & 8.0 & 0.85746 \\
\hline & 50.0 & 8.0 & 0.44369 \\
\hline & 100.0 & 8.0 & 0.48190 \\
\hline & 250.0 & 8.0 & 0.55473 \\
\hline \multirow{6}{*}{ OCI-AML2 } & TRAIL (ng/mL) & Bz $(\mathbf{n M})$ & CI \\
\hline & 10.0 & 8.0 & 1.27244 \\
\hline & 25.0 & 8.0 & 1.00502 \\
\hline & 50.0 & 8.0 & 0.62569 \\
\hline & 100.0 & 8.0 & 0.50518 \\
\hline & 250.0 & 8.0 & 0.41878 \\
\hline \multirow{6}{*}{ OCI-AML3 } & TRAIL (ng/mL) & Bz (nM) & CI \\
\hline & 10.0 & 10.0 & 0.46307 \\
\hline & 25.0 & 10.0 & 0.40560 \\
\hline & 50.0 & 10.0 & 0.40126 \\
\hline & 100.0 & 10.0 & 0.43864 \\
\hline & 250.0 & 10.0 & 0.42473 \\
\hline
\end{tabular}


Figure 5. Bortezomib sensitizes ML-1, ML-2, OCI AML2, OCI AML3 and MOLM13 to TRAIL induced apoptosis. AML cells were pre-treated with a sublethal dose of bortezomib that induced $20 \%$ cell death (2 nM (KG-1), 4 nM (KG-1, ML-2), $5 \mathrm{nM}$ (HL-60), $7 \mathrm{nM}$ (ML-1), $8 \mathrm{nM}$ (Kasumi, OCI AML2, MOLM13) or $10 \mathrm{nM}$ (OCI AML3)) for $18 \mathrm{~h}$ followed by a 18 h (KG-1, Kasumi, OCI AML3, ML-2) or 24 h (HL-60, ML-1, OCI AML2, MOLM13) treatment with 5, 10, 25, 50, 100, 250, 500 or $1000 \mathrm{ng} / \mathrm{mL}$ TRAIL. Cell viability was measured by MTT assay; values are expressed as a percent of untreated cells and presented as mean \pm S.E.M. (A) HL-60; (B) KG-1; (C) Kasumi; (D) OCI AML2; (E) OCI AML3; (F) MOLM13; (G) ML-2; (H) ML-1.

A

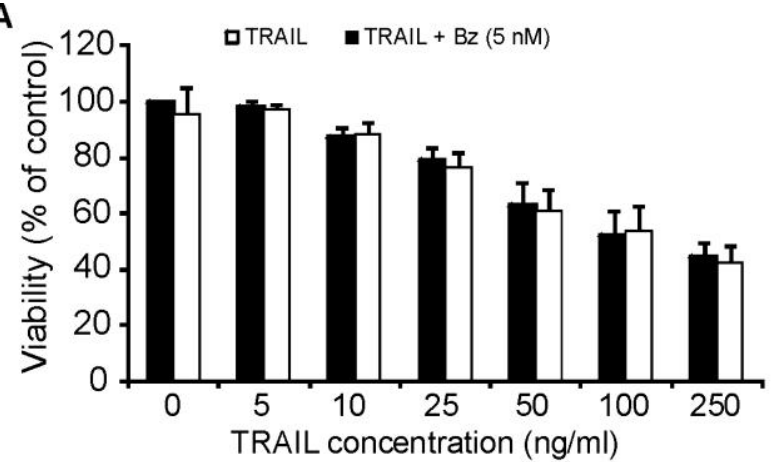

B

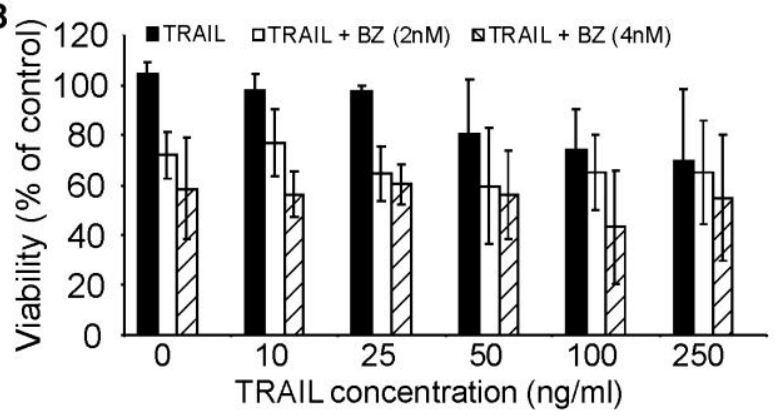

C
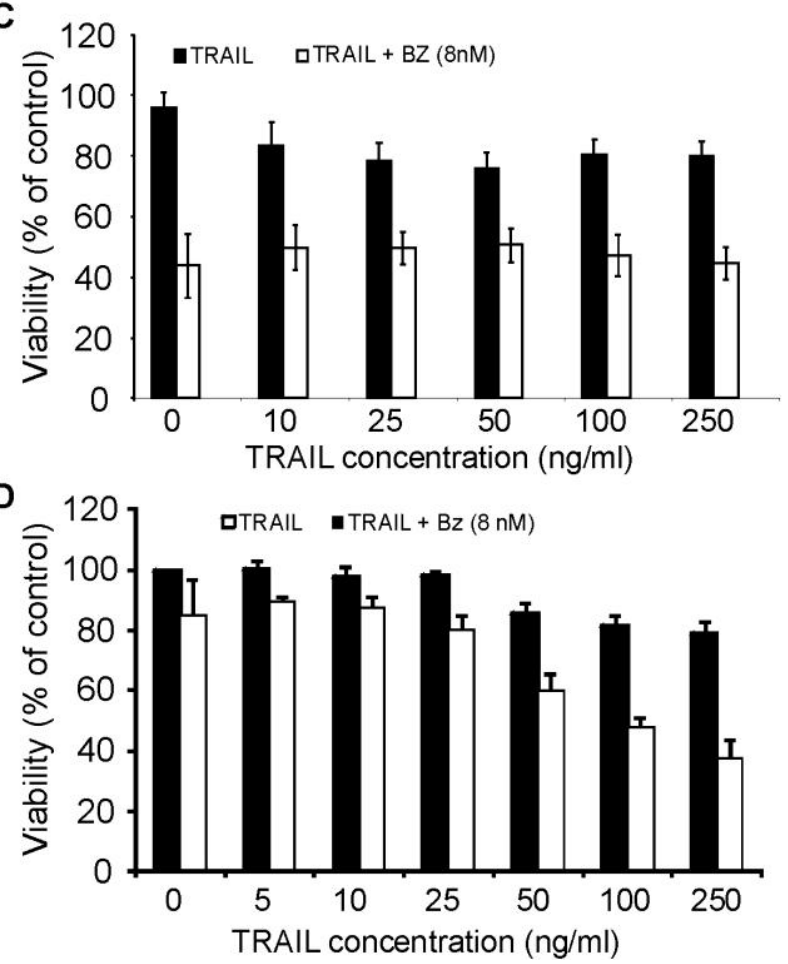

E
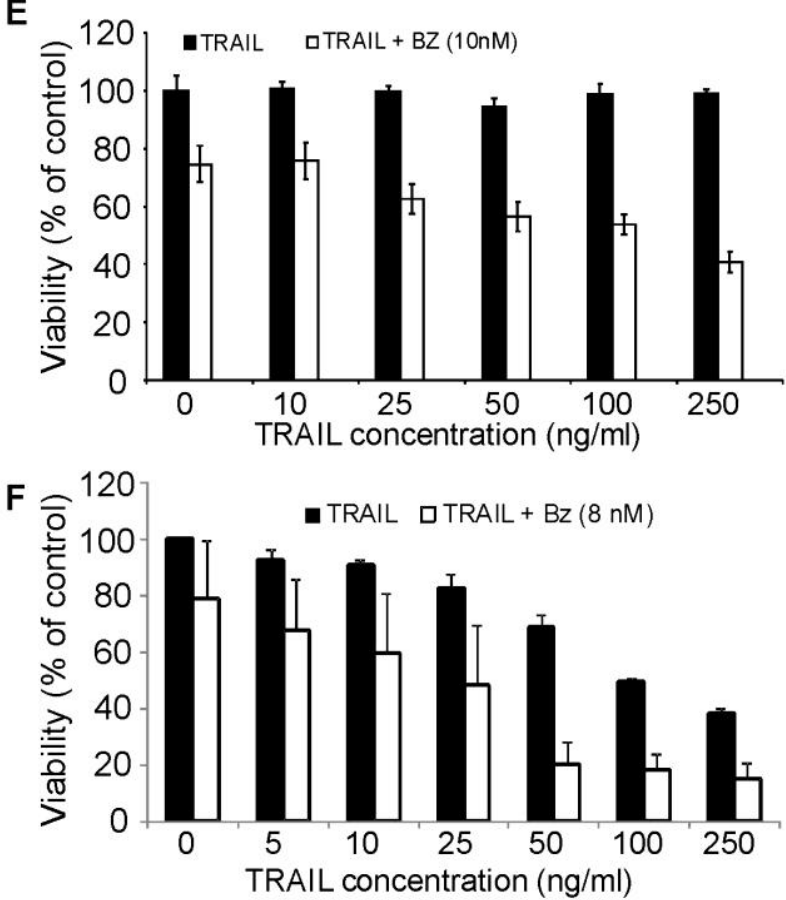

G
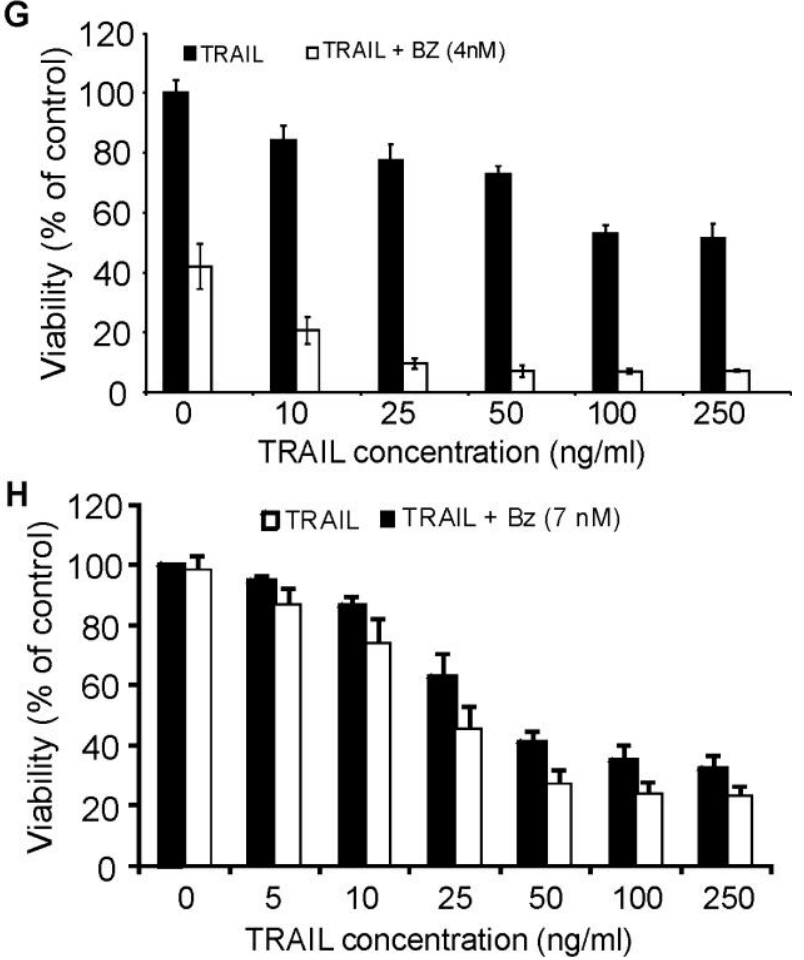


\subsection{Molecular Mechanism of Bortezomib-Induced Sensitization of Tumor Cells to rhTRAIL}

Roué and colleagues have shown that TRAIL resistance in mantle cell lymphoma cells is linked to $\mathrm{NF}-\kappa \mathrm{B}$ regulated expression of c-FLIP, the main endogenous regulator of caspase- 8 activation [35]. Expression of XIAP, another important inhibitor of TRAIL-induced apoptosis, has also been shown to

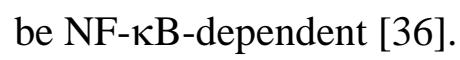

Since bortezomib can potentially inhibit NF- $\kappa \mathrm{B}$ activation, we analyzed the effect of bortezomib on the relative expression of the anti-apoptotic proteins, c-FLIP and XIAP in ML-1, OCI AML2 and OCI AML3 cells. The expression of c-FLIP was downregulated after bortezomib treatment (Figure 6A) in all three cell lines. XIAP was also downregulated post treatment with bortezomib with the exception of ML-1 cells which exhibited an increased expression, an effect which may be mediated by inhibition of XIAP degradation via the proteasome. In addition, we analyzed the effect of bortezomib on the expression of c-FLIP in HL-60, Kasumi and KG-1 cells. On the contrary, bortezomib did not reduce the expression of c-FLIP in HL-60, Kasumi and KG-1 cells, cell lines which bortezomib could not sensitize for TRAIL-induced apoptosis (Figure 6B).

As both c-FLIP and XIAP are known to be regulated by the NF- $\kappa \mathrm{B}$ pathway, our data supports the theory that inhibition of NF- $\kappa \mathrm{B}$ activation plays a central role in the sensitization of these particular AML types to TRAIL-induced apoptosis. To further investigate the role of NF- $\kappa \mathrm{B}$ in bortezomib-mediated sensitisation, ML-1, OCI AML2 and OCI AML3 cells were pre-treated with the inhibitor- $\kappa$ B kinase (IKK) inhibitor BMS-345541 [37] for $15 \mathrm{~h}$ followed by a $24 \mathrm{~h}$ treatment with rhTRAIL. BMS-345541 could sensitize all three cell lines to rhTRAIL-induced apoptosis (Figure 7A-C), which was associated with the downregulation of c-FLIP and XIAP expression in OCI AML2 cells (Figure 7D) lending further support to the importance of NF- $\mathrm{BB}$ inhibition in bortezomib-induced sensitization to TRAIL.

Figure 6. Bortezomib treatment leads to downregulation of c-FLIP and XIAP in FAB M4/M5 AML cells. Cells were treated with (A) $7 \mathrm{nM}$ (ML-1), $16 \mathrm{nM}$ (OCI AML2) or $25 \mathrm{nM}$ (OCI AML3) bortezomib or (B) $2 \mathrm{nM}$ (HL60, KG-1), $4 \mathrm{nM}$ (HL60) or $8 \mathrm{nM}$ (Kasumi) bortezomib for $18 \mathrm{~h}$ after which cell lysates were harvested and analyzed for c-FLIP and XIAP expression by Western blotting. Expression of actin was detected to serve as a loading control.

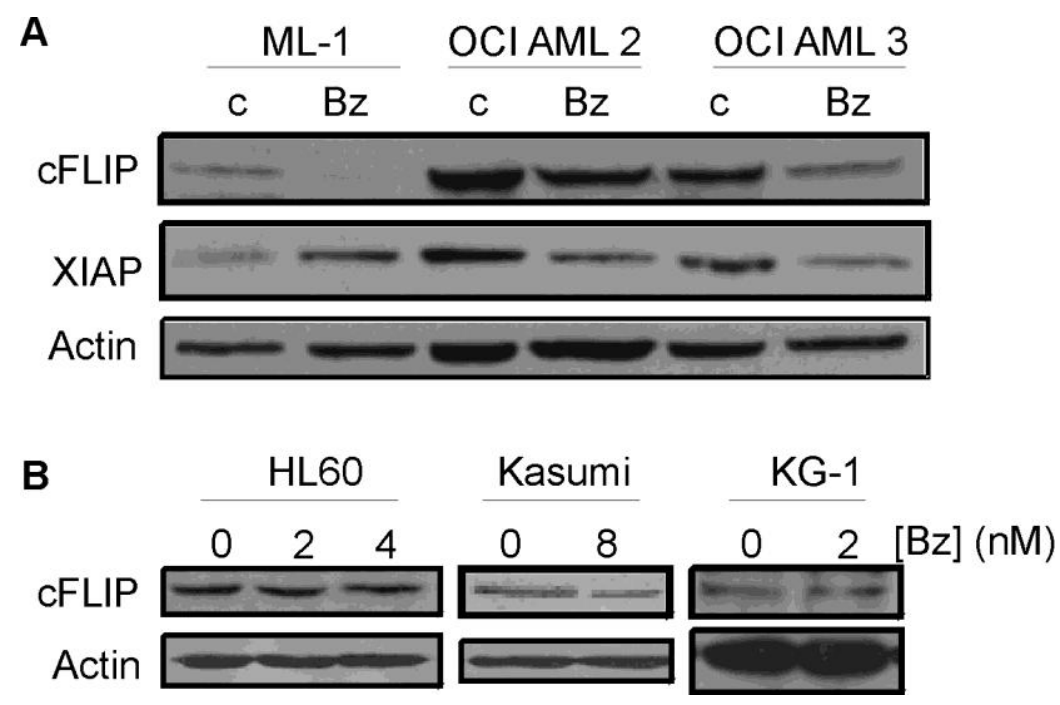


Figure 7. NF- $\kappa B$ inhibition sensitizes ML-1, OCI AML2 and OCI AML3 to TRAIL-induced apoptosis. (A-C) AML cells were pre-treated with 2, 5 or $7.5 \mu \mathrm{M}$ BMS-345541 for $15 \mathrm{~h}$ followed by a treatment with $10 \mathrm{ng} / \mathrm{mL}$ (ML-1) or $250 \mathrm{ng} / \mathrm{mL}$ TRAIL (OCI AML2 and OCI AML3) for $24 \mathrm{~h}$. Induction of cell death was measured by Annexin V staining. Data shown are mean \pm S.E.M. (A) ML-1; (B) OCI AML2; (C) OCI AML3; (D) OCI AML2 cells were treated with $5 \mu \mathrm{M}$ BMS-345541 for $0,4,6,8$ or $10 \mathrm{~h}$ after which cell lysates were harvested and analyzed for c-FLIP and XIAP expression by Western blotting. Expression of actin was detected to serve as a loading control.
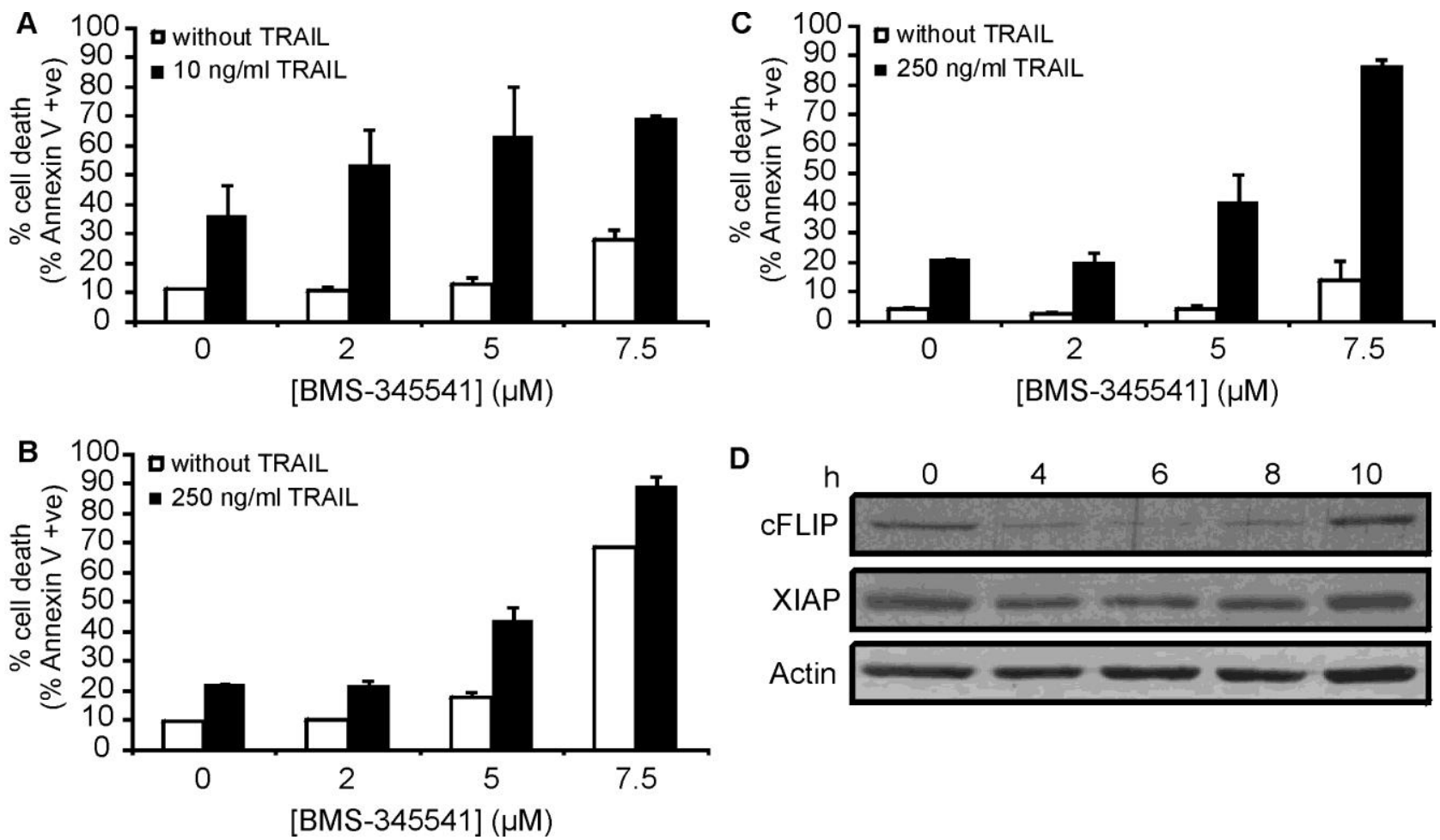

D

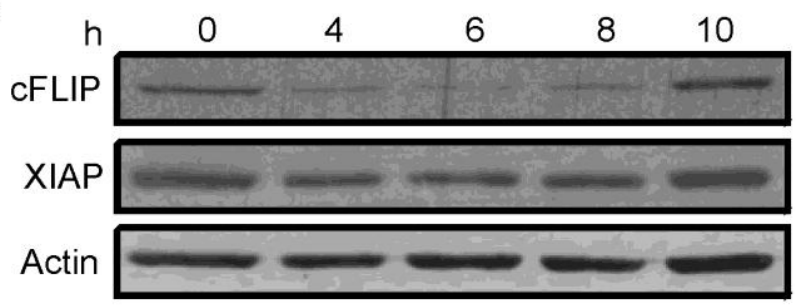

\subsection{Inhibition of $N F-\kappa B$ Sensitized Myelomonocytic Primary AML Cells to TRAIL-Induced Apoptosis}

Analysis of primary AML blasts further supported the importance of NF- $\kappa B$ activity in rhTRAIL resistance (Figure 8). AML blasts were isolated from bone marrow or peripheral blood of patients and treated with BMS-345541 in combination with rhTRAIL for $24 \mathrm{~h}$. The patient information and the expression profile of the four membrane bound TRAIL receptors (DR4, DR5, Decoy receptor 1 (DcR1 and DcR2) on the cell surface are summarized in Table 2 and Table 3, respectively. We found that a small subset of patient AML cells was already sensitive to TRAIL (patients 2, 7, 9) and in these samples inhibition of NF- $\kappa$ B only marginally increased TRAIL sensitivity (Figure 8A). Some AML samples required NF- $\kappa \mathrm{B}$ activity for survival, and accordingly, in these samples administration of BMS-345541 alone already induced high level of cell death (Figure 8B). However, approximately half of the samples tested showed TRAIL resistance and in these samples, inhibition of NF- $\kappa \mathrm{B}$ significantly increased TRAIL sensitivity (Figure 8C) indicated by the median difference between the cytotoxic effect of BMS-345541 vs. TRAIL+ BMS-345541 and TRAIL vs. TRAIL+BMS-345541 (13.94\% and $28.02 \%$, respectively), and $p$ values determined by two tailed paired student t-test (0.038 and 0.002 , for the same treatment pairs). 
Table 2. Clinical parameters for patient samples.

\begin{tabular}{|c|c|c|c|c|c|c|c|c|c|c|c|}
\hline 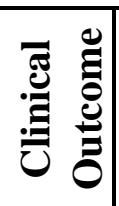 & 艺 & 兄 & 艺 & 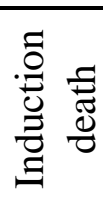 & 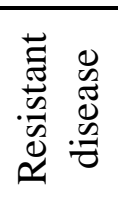 & 艺 & 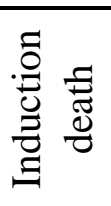 & 次 & 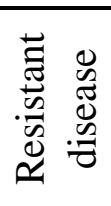 & 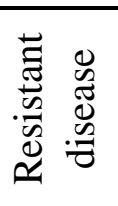 & . \\
\hline 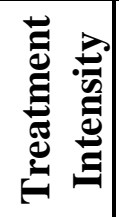 & 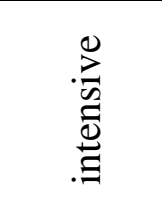 & 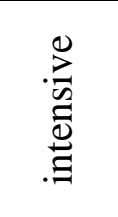 & 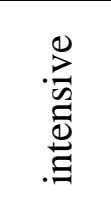 & 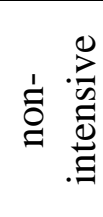 & 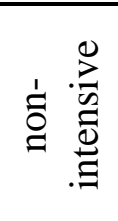 & 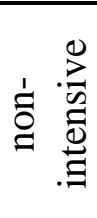 & 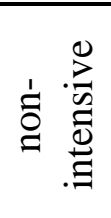 & 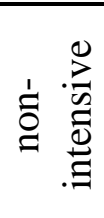 & 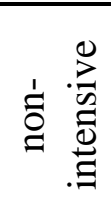 & 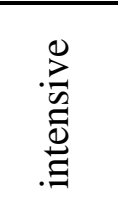 & 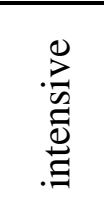 \\
\hline 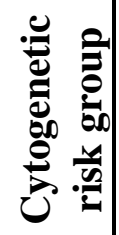 & 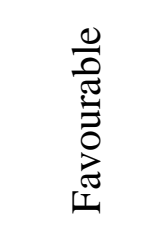 & 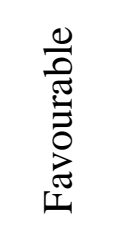 & 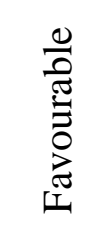 & 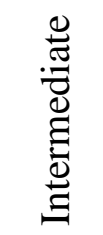 & 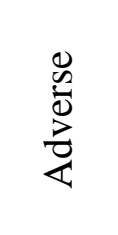 & 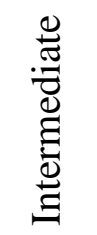 & & 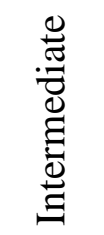 & 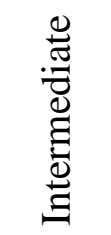 & 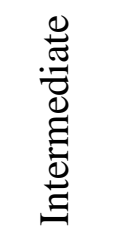 & 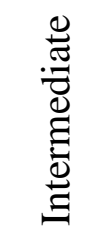 \\
\hline 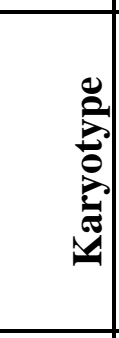 & 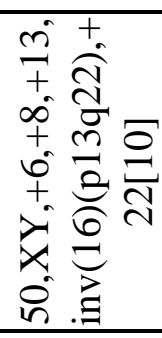 & 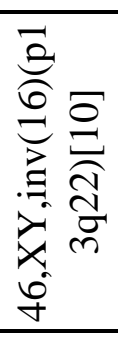 & 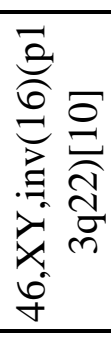 & 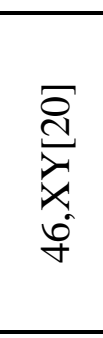 & 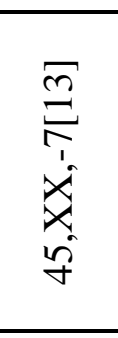 & 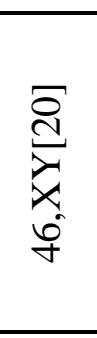 & & 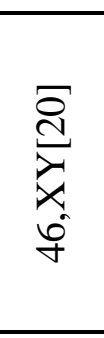 & 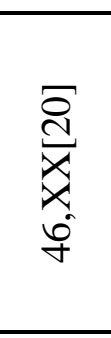 & 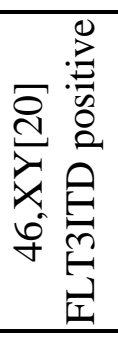 & 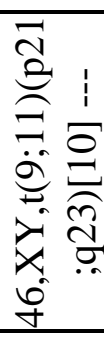 \\
\hline$\sum^{0}$ & $\frac{\infty}{\sigma}$ & $\nabla$ & $\frac{t}{0}$ & $\stackrel{f}{q}$ & $\stackrel{n}{n}$ & $\begin{array}{l}\infty \\
\stackrel{f}{f}\end{array}$ & $\hat{\infty}$ & 음 & ț & $\stackrel{n}{\beth}$ & $\tilde{g}$ \\
\hline 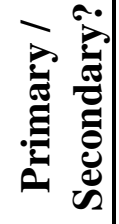 & 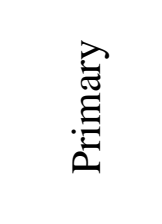 & $\stackrel{\vec{E}}{:}$ & 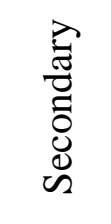 & $\stackrel{\vec{\Xi}}{\Xi}$ & $\stackrel{\vec{\Xi}}{\Xi}$ & 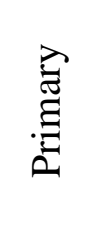 & 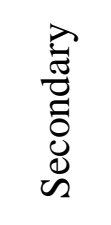 & $\stackrel{\overparen{\Xi}}{\Xi}$ & 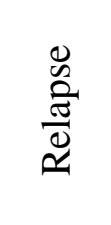 & $\stackrel{\overparen{Z}}{\Xi}$ & $\stackrel{\vec{\Xi}}{\Xi}$ \\
\hline$\underset{8}{80}$ & $\bar{n}$ & $m$ & $\stackrel{\text { Y }}{ }$ & $\infty$ & 8) & $\mathscr{\infty}$ & $\infty$ & $\hat{\imath}$ & $\mathbb{N}$ & $\stackrel{\infty}{+}$ & గ్ర \\
\hline 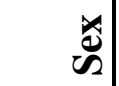 & $\Sigma$ & $\Sigma$ & $\Sigma$ & $\Sigma$ & 工 & $\Sigma$ & I & $\Sigma$ & I & $\Sigma$ & $\Sigma$ \\
\hline$\sum_{\mathbb{1}}^{\infty}$ & $\stackrel{\&}{\sum}$ & $\sum^{ \pm}$ & $\stackrel{0}{\&}$ & $\begin{array}{l}\xi \\
\vdots \\
\Xi \\
\Xi \\
\Xi\end{array}$ & $\sum^{ \pm}$ & $\begin{array}{l}\vdots \\
\vdots \\
\vdots \\
\Xi \\
\Xi\end{array}$ & 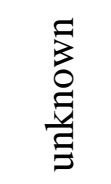 & $\bar{\Sigma}$ & $\stackrel{ \pm}{\Sigma}$ & $\bar{\Sigma}$ & $\stackrel{\mathscr{n}}{\Sigma}^{n}$ \\
\hline 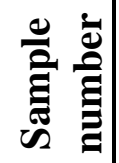 & N & $m$ & $n$ & $r$ & $\infty$ & $a$ & $\stackrel{0}{ }$ & 二 & $n$ & $\underline{0}$ & ㄷ \\
\hline
\end{tabular}

WBC: white blood cell count, AMML: acute myelomonocytic leukemia, CR: complete remission, Res Dis: residual disease 
Table 3. TRAIL receptor cell surface expression in primary AML blasts.

\begin{tabular}{|l|c|c|c|c|}
\hline & DR4 & DR5 & DcR1 & DcR2 \\
\hline $\mathbf{2}$ & + & + & - & +++ \\
\hline $\mathbf{3}$ & + & + & + & - \\
\hline $\mathbf{5}$ & + & + & - & + \\
\hline $\mathbf{7}$ & - & +++ & ++ & +++ \\
\hline $\mathbf{8}$ & + & + & + & + \\
\hline $\mathbf{9}$ & + & ++ & - & ++ \\
\hline $\mathbf{1 0}$ & - & - & - & + \\
\hline $\mathbf{1 1}$ & + & + & - & + \\
\hline $\mathbf{1 5}$ & + & - & ++ & ++ \\
\hline $\mathbf{1 6}$ & - & + & + & - \\
\hline $\mathbf{1 7}$ & - & - & - & - \\
\hline
\end{tabular}

+ : low level of expression (geometric mean on histogram is $120-200 \%$ of isotype control); ++ : medium level of expression (geometric mean is $200-300 \%$ of isotype control); +++: high level of expression (geometric mean is more than $300 \%$ of isotype control).

Figure 8. NF- $\kappa B$ inhibition sensitizes resistant primary AML blasts to rhTRAIL. AML blasts were treated with $250 \mathrm{ng} / \mathrm{mL}$ of rhTRAIL in the presence or absence of the IKK inhibitor BMS-345541 for $24 \mathrm{~h}$. Induction of cell death was detected with Annexin V staining. The bars indicate the mean values of the samples represented by the individual lines. (A) Patient subset with rhTRAIL sensitive AML blasts; (B) Patient samples with high BMS-345541 sensitivity; (C) rhTRAIL-resistant AML sample group.

A

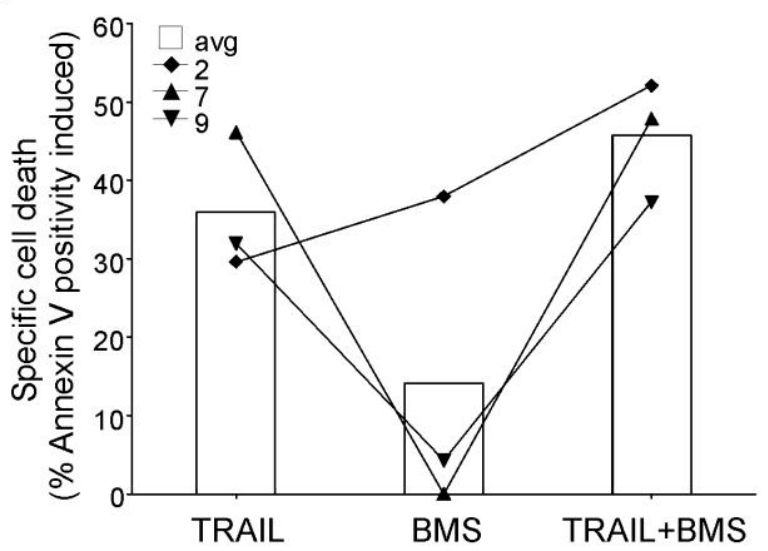

C

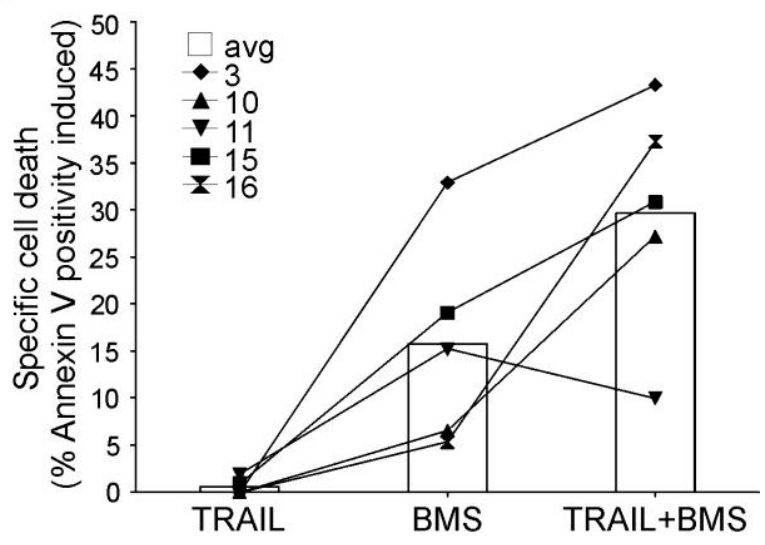

B

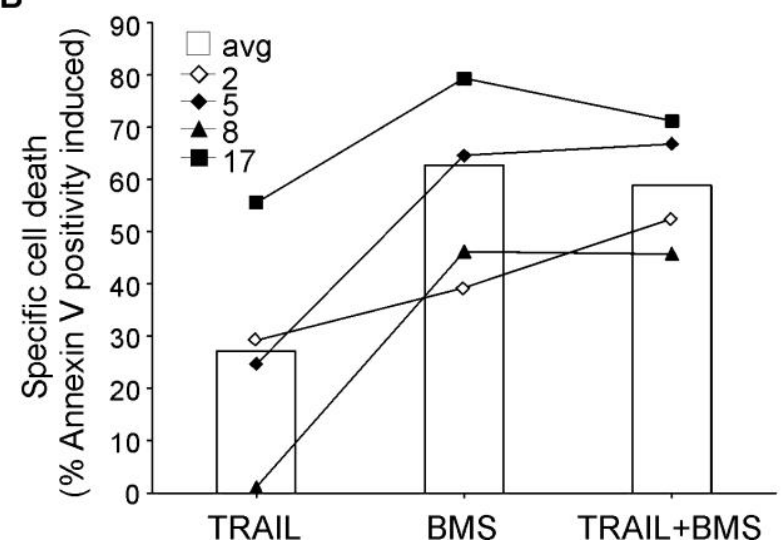




\subsection{Discussion}

TRAIL targets cancer cells whilst largely sparing normal cells and is therefore a very promising therapeutic modality. However, AML is largely resistant to TRAIL-induced apoptosis, due to inhibition or lack of expression of the apoptosis-inducing TRAIL receptors (DR4, DR5) and overexpression of intracellular anti-apoptotic factors, such as c-FLIP [33]. There is a strong rationale for using bortezomib to overcome TRAIL resistance based on the known influence of bortezomib on the proteins regulating the TRAIL apoptotic pathway, however, currently there is limited information on the potential of bortezomib to sensitize AML to rhTRAIL [38]. Our data reveal that bortezomib exerts potent pro-apoptotic effects against AML in vitro in the nanomolar range and also sensitizes AML cells of myelomonocytic/monocytic phenotype, which account for 20-30\% of AML cases [39], to rhTRAIL, an effect which is at least partly mediated by inhibition of NF- $\kappa \mathrm{B}$ and by reducing c-FLIP and XIAP expression, which is consistent with similar findings in other cancer cells [30,40-42]. Proteasome inhibitors have previously been shown to decrease c-FLIP protein expression in murine leukemia cells, renal cancer cells and chronic lymphocytic leukemia (CLL) cells, which was associated with sensitization to rhTRAIL [30,41].

Previous studies have also established that expression of the caspase- 9 and caspase- 3 inhibitory protein, XIAP, increases with monocytic differentiation and in adult de novo AML high XIAP expression correlates with poor prognosis [43]. It has also been shown that similar to c-FLIP, XIAP is also a transcriptional target of NF- $\mathrm{KB}$ [36]. Here we demonstrate higher basal expression of XIAP in the FAB M4 TRAIL-resistant cell lines OCI AML2 and OCI AML3 with a clear reduction post treatment with bortezomib. In the TRAIL-sensitive cell line ML-1, however, the opposite effect occurs, which may suggest differences in regulation of XIAP levels in various AML cells and indicates that in AML, XIAP downregulation may contribute to an enhanced response to TRAIL but it is not essential.

Constitutive NF- $\kappa \mathrm{B}$ activity has been detected in a number of hematological malignancies, such as Hodgkin's disease (HD), acute lymphoblastic leukemia (ALL) as well as AML [26,44-46]. As c-FLIP

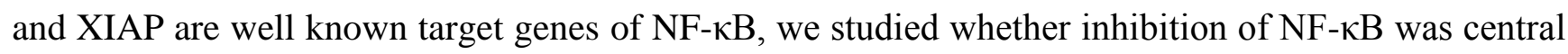
to the sensitizing effect of bortezomib on TRAIL-induced apoptosis using a chemical inhibitor of IкB kinase, BMS-345541 [37]. Our data demonstrate an enhancement of TRAIL-induced apoptosis in AML cell lines of myelomonocytic differentiation as well as in primary AML blasts of myelomonocytic/monocytic differentiation by inhibition of IKK. This, together with the detected repression of c-FLIP and XIAP expression after inhibition of IKK supports the hypothesis that sensitisation to TRAIL is at least partly due to bortezomib-mediated inhibition of NF- $\mathrm{B}$ activity/activation. Since TRAIL binding to its receptors also activates NF- $\mathrm{B}$, it is also plausible that proteasome inhibition may enhance TRAIL-mediated apoptosis principally by blocking TRAIL-mediated NF- $\kappa \mathrm{B}$ activation, thereby preventing the expression of anti-apoptotic proteins, including c-FLIP and XIAP. Ubiquitylation is involved in at least three steps in the NF- $\kappa \mathrm{B}$ activation pathway: degradation of the NF- $\kappa \mathrm{B}$ inhibitor $\mathrm{I} \kappa \mathrm{B}$, processing of the p100 and p105 NF- $\mathrm{B}$ precursors and activation of the I $\mathrm{K} B$ kinase (IKK) through a degradation-independent mechanism [47]. Bortezomib not only inhibits TRAIL-mediated NF- $\kappa \mathrm{B}$ activation by blocking the proteasomal degradation of polyubiquitylated (Lys48)-IкB or processing of p100 and p105, but also leads to the depletion of the cellular pool of free-ubiquitin. This prevents the non-degradational, Lys63-type poly- 
ubiquitylation of TRAIL receptor adaptor proteins, which is essential for recruitment of IKKs and thus for NF- $\kappa \mathrm{B}$ activation [47]. Of note, Baumgartner and colleagues have shown that enhanced NF- $\mathrm{B}$ activity driven by aberrant IKK activity is a characteristic of myelomonocytic FAB M4 and monocytic/monoblastic M5 AML blasts, but not of AML of early or granulocytic differentiation. Furthermore, in M4/M5 AML blasts treatment with the TRAIL homologue death ligand, tumor necrosis factor (TNF) could further increase NF- $\kappa$ B activity which could be blocked by proteasome inhibition with PS-I [45]. In line with these, we found that all BMS345541-sensitive patient samples were of FAB M4/M5 subtype, reinforcing the finding that myelomonocytic/monocytic AML cells depend on NF- $\kappa B$ activity. Additionally, two out of the four primary samples that could be sensitized to TRAIL with inhibition of NF- $\kappa$ B activation were also FAB M4. These findings strongly indicate that there are differentiation associated differences in TRAIL resistance of AML subtypes and the

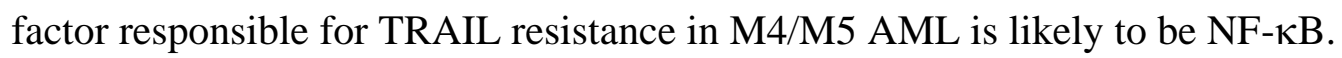

M1- and M2-type AML blasts have higher levels and activity of the multidrug receptor (MDR-1) and P-glycoprotein driven efflux of therapeutic drugs [48,49], however bortezomib was able to block the proteasome in all tested cell lines at a very similar efficacy $\left(\mathrm{IC}_{50}\right.$ value was between 1.9 to $5 \mathrm{nM}$ for all cell lines), eliminating this as a reason for the lack of bortezomib-mediated TRAIL-sensitization. Thus in M1/M2 AML's different mechanisms must block TRAIL-death signaling. Identification of these mechanisms is still awaited. Furthermore, we did not detect any correlation between the effect of bortezomib on the three different enzyme activities of the proteasome, except that the two cell lines with the highest basal proteasome activity (KG-1 and MOLM13) were the most sensitive to the cytotoxic effect of bortezomib. It may indicate that these cells depend on the proteasome to survive. These findings are in agreement with the study of Matondo et al., which also found that elevated 20S expression and high proteasome activity correlated with high bortezomib sensitivity in AML cells [50].

With the realisation of the central role of $N F-\kappa B$ in maintaining leukemic cell survival and drug resistance, ongoing studies are examining the potential of NF- $\kappa \mathrm{B}$ inhibition in AML therapy using bortezomib. Importantly, not only the AML blast cells, but also the quiescent leukemic stem cell

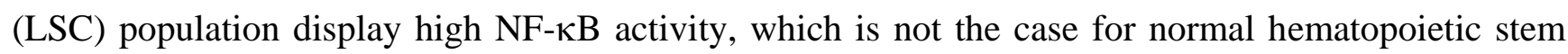
cells and inhibition of NF- $\kappa \mathrm{B}$ by bortezomib can effectively target this cell population [27]. The proteasome system is the main, non-lysosomal protein degradation system in the cell controlling the cell cycle, gene transcription, cellular adhesion, etc. Systemic blockage of such essential cellular functions can result in severe toxicities such as thrombocytopenia, cardiopulmonary- and neurologic toxicities, which limits the maximum dose and the frequency of bortezomib administration to approximately $1.5 \mathrm{mg} / \mathrm{m}^{2}$ bi-weekly [51-54]. The in vivo half-life time of bortezomib is in the range of 10-18 $\mathrm{h} \mathrm{[29]} \mathrm{and} \mathrm{when} \mathrm{administered} \mathrm{at} \mathrm{the} \mathrm{highest} \mathrm{recommended} \mathrm{dose,} \mathrm{proteasomal} \mathrm{inhibition} \mathrm{was} \mathrm{the}$ highest $1 \mathrm{~h}$ post administration in peripheral blood mononuclear cells with approximately $70 \%$ inhibition of baseline levels that was reduced to about $50 \%$ at $24 \mathrm{~h}$ [55]. The resulting fluctuating proteasome inhibition, even at the maximum tolerated dose, may be insufficient to achieve potent $\mathrm{NF}-\kappa \mathrm{B}$ inhibition in vivo necessary for effective AML eradication. Thus, alternate strategies, capable of targeting NF- $\mathrm{B}$ in a more sustained fashion than bortezomib would be potentially attractive AML therapeutics [56,57]. 


\section{Experimental Section}

\subsection{Cell Culture and Treatments}

HL-60 (ATCC), ML-1 (kindly received from Dr. Heinz-Peter Nasheur, Biochemistry Department, NUI Galway) and ML-2 cells (German Collection of Microorganisms and Cell cultures, DSMZ) were maintained in RPMI1640 supplemented with 10\% foetal bovine serum (FBS), 2 mM glutamine, $50 \mathrm{U} / \mathrm{mL}$ penicillin and $50 \mu \mathrm{g} / \mathrm{mL}$ streptomycin. Cells were seeded at $3 \times 10^{5}$ cells $/ \mathrm{mL}$ one day prior to treatment. Kasumi, MOLM13 and KG-1 cells (kindly received from Dr. Elisabeth Kremmer, Institute for Molecular Immunology, Munchen, Germany) were maintained in RPMI 1640 supplemented with $10 \%$ FBS, $2 \mathrm{mM}$ glutamine, $1 \mathrm{mM}$ sodium pyruvate, $1 \%$ non-essential amino acids (NEA), $50 \mathrm{U} / \mathrm{mL}$ penicillin and $50 \mu \mathrm{g} / \mathrm{mL}$ streptomycin. Cells were seeded at $5 \times 10^{5}$ cells $/ \mathrm{mL}$ one day prior to treatment. OCI AML2 and OCI AML3 cells (DSMZ) were maintained in Alpha Minimum Essential Medium (MEM) supplemented with $10 \% \mathrm{FBS}, 2 \mathrm{mM}$ glutamine, $1 \mathrm{mM}$ sodium pyruvate, $1 \% \mathrm{NEA}, 50 \mathrm{U} / \mathrm{mL}$ penicillin and $50 \mu \mathrm{g} / \mathrm{mL}$ streptomycin. Cells were seeded at $5 \times 10^{5}$ cells $/ \mathrm{mL}$ one day prior to treatment.

Bortezomib (Janssen, UK) was dissolved in DMSO and used in a concentration range of 2-100 nM. BMS-345541 (Calbiochem) was dissolved in DMSO and used in a concentration range of 2-10 $\mu \mathrm{M}$. The formulation of recombinant human TRAIL was non-tagged, fragment 114-281, kindly provided by Wim Quax, University of Groningen, The Netherlands. All materials were from Sigma, unless otherwise stated.

\subsection{MTT Cell Viability Assay}

Cell viability was measured by adding $200 \mu \mathrm{g} / \mathrm{mL}$ MTT (3-(4,5-dimethylthiazol-2-yl)-2,5-diphenyltetrazolium bromide) to control and treated cells, and incubated for $3 \mathrm{~h}$ at $37{ }^{\circ} \mathrm{C}$. The reaction was stopped and the purple formazan precipitate formed was dissolved in 20\% SDS in 50\% dimethyl formamide and the color intensity was measured at $550 \mathrm{~nm}$ using a Wallac multilabel counter (PerkinElmer). The control value corresponding to untreated cells was taken as $100 \%$ and the viability of treated samples was expressed as a percentage of the control.

\subsection{Annexin V staining}

Externalization of phosphatidylserine (PS) on the plasma membrane of apoptotic cells was detected using Annexin V-FITC (IQ Corporation). Briefly, cells were collected by trypsinization and allowed to recover for $10 \mathrm{~min}$ in growth medium. The cells were then washed in ice-cold calcium buffer $(10 \mathrm{mM}$ HEPES/NaOH, pH 7.4, $140 \mathrm{mM} \mathrm{NaCl}, 2.5 \mathrm{mM} \mathrm{CaCl}_{2}$ ) and incubated with Annexin V-FITC for 15 min in the dark.

\subsection{Western Blotting}

After treatments cells were lysed in $100 \mu \mathrm{L}$ buffer (20 mM HEPES, pH 7.5, $350 \mathrm{mM} \mathrm{NaCl}, 1 \mathrm{mM}$ $\mathrm{MgCl}_{2}, 0.5 \mathrm{mM}$ ethylenediamine-tetraacetic acid (EDTA), $0.1 \mathrm{mM}$ ethylene glycol bis(2-aminoethyl ether)-N,N,N'N'-tetraacetic acid (EGTA), 1\% Igepal-630, $0.5 \mathrm{mM}$ dithiothreitol (DTT), $100 \mu \mathrm{M}$ phenylmethyl-sulphonyl fluoride (PMSF), $2 \mu \mathrm{g} / \mathrm{mL}$ pepstatin A, $25 \mu \mathrm{M}$ N-Acetyl-Leu-Leu-Nle-CHO 
(ALLN), $2.5 \mu \mathrm{g} / \mathrm{mL}$ aprotinin and $10 \mu \mathrm{M}$ leupeptin) for $15 \mathrm{~min}$ on ice. Protein concentration was measured using the Bradford method. Protein samples were denatured in Laemmli's sample buffer and boiled for $5 \mathrm{~min}$. Proteins were separated by 10\% SDS-PAGE and transferred onto nitrocellulose membrane. Membranes were blocked for $1 \mathrm{~h}$ in PBS containing 0.05\% Tween 20 and 5\% (w/v) non-fat dried milk. The membranes were then incubated for $1 \mathrm{~h}$ at room temperature with antibodies to actin (1:500; Sigma) or overnight at $4{ }^{\circ} \mathrm{C}$ with antibodies to c-FLIP (1:500; Alexis), or XIAP (1:5000; Assay Design). This was followed by $2 \mathrm{~h}$ incubation at room temperature with appropriate secondary antibodies (1:10,000 Thermo Scientific). Protein bands were visualized using Supersignal Ultra Chemiluminescent Substrate (Thermo Scientific) on X-ray film (Agfa).

\subsection{Proteasome Activity Assay}

The chymotryptic, tryptic and PGPH (peptidylglutamyl peptide hydrolyzing) activities of the proteasome were measured by using specific, fluorescently tagged peptide substrates (N-SuccinylLLVY-AMC, Z-ARR-AMC and Z-LLE-AMC (all from Merck), respectively). Following treatment, cells were lysed in $50 \mu \mathrm{L}$ of lysis buffer (13 mM Tris buffer containing $5 \mathrm{mM} \mathrm{MgCl}_{2}, \mathrm{pH} 7.8$ ) through two freeze-thaw cycles. The samples were divided into $2 \times 25 \mu \mathrm{L}$ and a $175 \mathrm{~mL}$ of substrate buffer added (5 mM ATP, $0.5 \mathrm{mM}$ DTT, $5 \mathrm{mM}$ EDTA and $50 \mu \mathrm{M}$ proteasomal substrate in lysis buffer). Activity was measured as a rate of cleavage of fluorogenic substrates and was determined by monitoring the fluorescence of released AMC (Amido 4-Methylcoumarin), using a fluorescent plate reader (Wallac/Victor 3, PerkinElmer) at an excitation wavelength of $395 \pm 25 \mathrm{~nm}$ and emission wavelength of $460 \pm 40 \mathrm{~nm}$. The assay was run over a period of $35 \mathrm{~min}$ (30 cycles, 1 measurement per min) at $37{ }^{\circ} \mathrm{C}$ and results were expressed in nmol AMC released/min/mg protein. The protein concentration of the lysates was determined by BCA protein assay (Pierce) according to the manufacturer's instructions.

\subsection{Isolation and Culture of Primary AML Blasts}

BM MNCs were isolated by density gradient centrifugation and cryopreserved in $10 \%$ dimethyl sulfoxide (DMSO) freezing medium. Following a rapid thawing and centrifugation to remove DMSO of the freezing medium, cells were cultured in RPMI/10\% fetal bovine serum. Cell viability was assessed at the time of thawing the cells and experiments were only carried out in samples that showed at least $75 \%$ viability. In addition, samples that showed high rate of spontaneous death and the percentage of live cells reduced to $25 \%$ or less at time of harvesting were also excluded from further analysis. The cells were treated with $250 \mathrm{ng} / \mathrm{mL}$ of WT rhTRAIL alone for $24 \mathrm{~h}$ or in combination with $5 \mu \mathrm{M}$ BMS-345541 added simultaneously.

\subsection{Determination of Surface TRAIL Receptor Expression}

Cells were removed from culture dishes, harvested by centrifugation and washed twice with $1 \%$ BSA in PBS. Cells were incubated with 1:100 dilution of primary antibodies (DR4 and DR5: neutralizing mouse monoclonal antibodies, Alexis, DcR1 and DcR2: neutralizing goat polyclonal antibodies, R\&D Systems) in 1\% BSA in PBS for 40 min on ice. After two washes in 1\% BSA/PBS, cells were resuspended in 1:50 dilution of FITC-labeled secondary antibody and incubated for $40 \mathrm{~min}$ 
on ice. Excess secondary antibody was removed by washing first in $1 \%$ BSA in PBS and then PBS. Cells were fixed in $1 \%$ formaldehyde/PBS before analysis by flow cytometry (FacsCalibur, Beckton Dickinson).

\section{Conclusions}

In summary, our results provide evidence to justify further investigation into the combination of rhTRAIL with bortezomib or ideally with selective inhibitors of NF- $\kappa \mathrm{B}$, to avoid affecting other cellular processes regulated by the proteasome. Such an approach will potentially lead to more effective AML therapy.

\section{Acknowledgements}

MvD is supported by an EMBARK fellowship from IRCSET, RM is supported by a fellowship under the MMI programme, Higher Education Authority (HEA), Ireland's EU Structural Funds (EUSF) by the Department of Enterprise, Science and Innovation and EM was supported by a fellowship from NUI, Galway. The authors would like to thank Janssen, UK for their generous gift of bortezomib. This work was financially supported by Cancer Care West and Science Foundation Ireland (09/SIRG/B1575).

\section{References}

1. Robak, T.; Wierzbowska, A. Current and emerging therapies for acute myeloid leukemia. Clin. Ther. 2009, 31, 2349-2370.

2. Deschler, B.; Lubbert, M. Acute myeloid leukemia: Epidemiology and etiology. Cancer 2006, 107, 2099-2107.

3. Nencioni, A.; Wille, L.; Dal Bello, G.; Boy, D.; Cirmena, G.; Wesselborg, S.; Belka, C.; Brossart, P.; Patrone, F.; Ballestrero, A. Cooperative cytotoxicity of proteasome inhibitors and tumor necrosis factor-related apoptosis-inducing ligand in chemoresistant bcl-2-overexpressing cells. Clin. Cancer Res. 2005, 11, 4259-4265.

4. Yagita, H.; Takeda, K.; Hayakawa, Y.; Smyth, M.J.; Okumura, K. Trail and its receptors as targets for cancer therapy. Cancer Sci. 2004, 95, 777-783.

5. Hylander, B.L.; Pitoniak, R.; Penetrante, R.B.; Gibbs, J.F.; Oktay, D.; Cheng, J.; Repasky, E.A. The anti-tumor effect of apo21/trail on patient pancreatic adenocarcinomas grown as xenografts in scid mice. J. Transl. Med. 2005, 3, 22.

6. Mitsiades, C.S.; Treon, S.P.; Mitsiades, N.; Shima, Y.; Richardson, P.; Schlossman, R.; Hideshima, T.; Anderson, K.C. Trail/apo2l ligand selectively induces apoptosis and overcomes drug resistance in multiple myeloma: Therapeutic applications. Blood 2001, 98, 795-804.

7. Naka, T.; Sugamura, K.; Hylander, B.L.; Widmer, M.B.; Rustum, Y.M.; Repasky, E.A. Effects of tumor necrosis factor-related apoptosis-inducing ligand alone and in combination with chemotherapeutic agents on patients' colon tumors grown in scid mice. Cancer Res. 2002, 62, 5800-5806. 
8. Riccioni, R.; Senese, M.; Diverio, D.; Riti, V.; Buffolino, S.; Mariani, G.; Boe, A.; Cedrone, M.; Lo-Coco, F.; Foa, R.; Peschle, C.; Testa, U. M4 and m5 acute myeloid leukaemias display a high sensitivity to bortezomib-mediated apoptosis. Br. J. Haematol. 2007, 139, 194-205.

9. Fesik, S.W. Promoting apoptosis as a strategy for cancer drug discovery. Nat. Rev. Cancer 2005, $5,876-885$.

10. Okano, H.; Shiraki, K.; Inoue, H.; Kawakita, T.; Yamanaka, T.; Deguchi, M.; Sugimoto, K.; Sakai, T.; Ohmori, S.; Fujikawa, K.; Murata, K.; Nakano, T. Cellular flice/caspase-8-inhibitory protein as a principal regulator of cell death and survival in human hepatocellular carcinoma. Lab Invest. 2003, 83, 1033-1043.

11. Siegmund, D.; Hadwiger, P.; Pfizenmaier, K.; Vornlocher, H.P.; Wajant, H. Selective inhibition of flice-like inhibitory protein expression with small interfering rna oligonucleotides is sufficient to sensitize tumor cells for trail-induced apoptosis. Mol. Med. 2002, 8, 725-732.

12. Malhi, H.; Gores, G.J. Trail resistance results in cancer progression: A trail to perdition? Oncogene 2006, 25, 7333-7335.

13. Adams, J. Proteasome inhibition in cancer: Development of ps-341. Semin. Oncol. 2001, 28, 613-619.

14. Adams, J.; Palombella, V.J.; Sausville, E.A.; Johnson, J.; Destree, A.; Lazarus, D.D.; Maas, J.; Pien, C.S.; Prakash, S.; Elliott, P.J. Proteasome inhibitors: A novel class of potent and effective antitumor agents. Cancer Res. 1999, 59, 2615-2622.

15. Elliott, P.J.; Ross, J.S. The proteasome: A new target for novel drug therapies. Am. J. Clin. Pathol. 2001, 116, 637-646.

16. Adams, J. The development of proteasome inhibitors as anticancer drugs. Cancer Cell 2004, 5, 417-421.

17. Glickman, M.H.; Ciechanover, A. The ubiquitin-proteasome proteolytic pathway: Destruction for the sake of construction. Physiol. Rev. 2002, 82, 373-428.

18. Mani, A.; Gelmann, E.P. The ubiquitin-proteasome pathway and its role in cancer. J. Clin. Oncol. 2005, 23, 4776-4789.

19. Melino, G. Discovery of the ubiquitin proteasome system and its involvement in apoptosis. Cell Death Differ. 2005, 12, 1155-1157.

20. Sterz, J.; von Metzler, I.; Hahne, J.C.; Lamottke, B.; Rademacher, J.; Heider, U.; Terpos, E.; Sezer, O. The potential of proteasome inhibitors in cancer therapy. Expert Opin. Investig. Drugs 2008, 17, 879-895.

21. Burger, A.M.; Seth, A.K. The ubiquitin-mediated protein degradation pathway in cancer: Therapeutic implications. Eur. J. Cancer 2004, 40, 2217-2229.

22. Hershko, A. The ubiquitin system for protein degradation and some of its roles in the control of the cell division cycle. Cell Death Differ. 2005, 12, 1191-1197.

23. Colado, E.; Alvarez-Fernandez, S.; Maiso, P.; Martin-Sanchez, J.; Vidriales, M.B.; Garayoa, M.; Ocio, E.M.; Montero, J.C.; Pandiella, A.; San Miguel, J.F. The effect of the proteasome inhibitor bortezomib on acute myeloid leukemia cells and drug resistance associated with the cd34+ immature phenotype. Haematologica 2008, 93, 57-66. 
24. Kumatori, A.; Tanaka, K.; Inamura, N.; Sone, S.; Ogura, T.; Matsumoto, T.; Tachikawa, T.; Shin, S.; Ichihara, A. Abnormally high expression of proteasomes in human leukemic cells. Proc. Natl. Acad. Sci. USA 1990, 87, 7071-7075.

25. Kraus, M.; Ruckrich, T.; Reich, M.; Gogel, J.; Beck, A.; Kammer, W.; Berkers, C.R.; Burg, D.; Overkleeft, H.; Ovaa, H.; Driessen, C. Activity patterns of proteasome subunits reflect bortezomib sensitivity of hematologic malignancies and are variable in primary human leukemia cells. Leukemia 2007, 21, 84-92.

26. Guzman, M.L.; Neering, S.J.; Upchurch, D.; Grimes, B.; Howard, D.S.; Rizzieri, D.A.; Luger, S.M.; Jordan, C.T. Nuclear factor-kappab is constitutively activated in primitive human acute myelogenous leukemia cells. Blood 2001, 98, 2301-2307.

27. Guzman, M.L.; Swiderski, C.F.; Howard, D.S.; Grimes, B.A.; Rossi, R.M.; Szilvassy, S.J.; Jordan, C.T. Preferential induction of apoptosis for primary human leukemic stem cells. Proc. Natl. Acad. Sci. USA 2002, 99, 16220-16225.

28. Cortes, J.; Thomas, D.; Koller, C.; Giles, F.; Estey, E.; Faderl, S.; Garcia-Manero, G.; McConkey, D.; Ruiz, S.L.; Guerciolini, R.; Wright, J.; Kantarjian, H. Phase i study of bortezomib in refractory or relapsed acute leukemias. Clin. Cancer Res. 2004, 10, 3371-3376.

29. Attar, E.C.; De Angelo, D.J.; Supko, J.G.; D'Amato, F.; Zahrieh, D.; Sirulnik, A.; Wadleigh, M.; Ballen, K.K.; McAfee, S.; Miller, K.B.; Levine, J.; Galinsky, I.; Trehu, E.G.; Schenkein, D.; Neuberg, D.; Stone, R.M.; Amrein, P.C. Phase i and pharmacokinetic study of bortezomib in combination with idarubicin and cytarabine in patients with acute myelogenous leukemia. Clin. Cancer Res. 2008, 14, 1446-1454.

30. Kabore, A.F.; Sun, J.; Hu, X.; McCrea, K.; Johnston, J.B.; Gibson, S.B. The trail apoptotic pathway mediates proteasome inhibitor induced apoptosis in primary chronic lymphocytic leukemia cells. Apoptosis 2006, 11, 1175-1193.

31. Liu, X.; Yue, P.; Chen, S.; Hu, L.; Lonial, S.; Khuri, F.R.; Sun, S.Y. The proteasome inhibitor ps341 (bortezomib) up-regulates dr5 expression leading to induction of apoptosis and enhancement of trail-induced apoptosis despite up-regulation of c-flip and survivin expression in human nsclc cells. Cancer Res. 2007, 67, 4981-4988.

32. Smith, M.R.; Jin, F.; Joshi, I. Bortezomib sensitizes non-hodgkin's lymphoma cells to apoptosis induced by antibodies to tumor necrosis factor related apoptosis-inducing ligand (trail) receptors trail-r1 and trail-r2. Clin. Cancer Res. 2007, 13, 5528s-5534s.

33. Koschny, R.; Holland, H.; Sykora, J.; Haas, T.L.; Sprick, M.R.; Ganten, T.M.; Krupp, W.; Bauer, M.; Ahnert, P.; Meixensberger, J.; Walczak, H. Bortezomib sensitizes primary human astrocytoma cells of who grades $\mathrm{i}$ to iv for tumor necrosis factor-related apoptosis-inducing ligand-induced apoptosis. Clin. Cancer Res. 2007, 13, 3403-3412.

34. Koschny, R.; Ganten, T.M.; Sykora, J.; Haas, T.L.; Sprick, M.R.; Kolb, A.; Stremmel, W.; Walczak, H. Trail/bortezomib cotreatment is potentially hepatotoxic but induces cancer-specific apoptosis within a therapeutic window. Hepatology 2007, 45, 649-658.

35. Roue, G.; Perez-Galan, P.; Lopez-Guerra, M.; Villamor, N.; Campo, E.; Colomer, D. Selective inhibition of ikappab kinase sensitizes mantle cell lymphoma b cells to trail by decreasing cellular flip level. J. Immunol. 2007, 178, 1923-1930. 
36. Stehlik, C.; de Martin, R.; Kumabashiri, I.; Schmid, J.A.; Binder, B.R.; Lipp, J. Nuclear factor (nf)-kappab-regulated x-chromosome-linked iap gene expression protects endothelial cells from tumor necrosis factor alpha-induced apoptosis. J. Exp Med. 1998, 188, 211-216.

37. Burke, J.R.; Pattoli, M.A.; Gregor, K.R.; Brassil, P.J.; MacMaster, J.F.; McIntyre, K.W.; Yang, X.; Iotzova, V.S.; Clarke, W.; Strnad, J.; Qiu, Y.; Zusi, F.C. Bms-345541 is a highly selective inhibitor of $\mathrm{i}$ kappa $\mathrm{b}$ kinase that binds at an allosteric site of the enzyme and blocks nf-kappa bdependent transcription in mice. J. Biol. Chem. 2003, 278, 1450-1456.

38. Conticello, C.; Adamo, L.; Vicari, L.; Giuffrida, R.; Iannolo, G.; Anastasi, G.; Caruso, L.; Moschetti, G.; Cupri, A.; Palumbo, G.A.; Gulisano, M.; De Maria, R.; Giustolisi, R.; Di Raimondo, F. Antitumor activity of bortezomib alone and in combination with trail in human acute myeloid leukemia. Acta Haematol. 2008, 120, 19-30.

39. Stanley, M., McKenna, R.W., Ellinger, G., Eds.; Classification of 358 Cases of Acute Myeloid Leukemia by Fab Criteria: Analysis of Clinical and Morphologic Features; Martin Nijhoff Publishers: Boston, MA, USA, 1985.

40. Khanbolooki, S.; Nawrocki, S.T.; Arumugam, T.; Andtbacka, R.; Pino, M.S.; Kurzrock, R.; Logsdon, C.D.; Abbruzzese, J.L.; McConkey, D.J. Nuclear factor-kappab maintains trail resistance in human pancreatic cancer cells. Mol. Cancer Ther. 2006, 5, 2251-2260.

41. Sayers, T.J.; Brooks, A.D.; Koh, C.Y.; Ma, W.; Seki, N.; Raziuddin, A.; Blazar, B.R.; Zhang, X.; Elliott, P.J.; Murphy, W.J. The proteasome inhibitor ps-341 sensitizes neoplastic cells to trailmediated apoptosis by reducing levels of c-flip. Blood 2003, 102, 303-310.

42. Zhao, X.; Qiu, W.; Kung, J.; Peng, X.; Yegappan, M.; Yen-Lieberman, B.; Hsi, E.D. Bortezomib induces caspase-dependent apoptosis in hodgkin lymphoma cell lines and is associated with reduced c-flip expression: A gene expression profiling study with implications for potential combination therapies. Leuk. Res. 2008, 32, 275-285.

43. Tamm, I.; Richter, S.; Scholz, F.; Schmelz, K.; Oltersdorf, D.; Karawajew, L.; Schoch, C.; Haferlach, T.; Ludwig, W.D.; Wuchter, C. Xiap expression correlates with monocytic differentiation in adult de novo aml: Impact on prognosis. Hematol. J. 2004, 5, 489-495.

44. Bargou, R.C.; Leng, C.; Krappmann, D.; Emmerich, F.; Mapara, M.Y.; Bommert, K.; Royer, H.D.; Scheidereit, C.; Dorken, B. High-level nuclear nf-kappa b and oct-2 is a common feature of cultured hodgkin/reed-sternberg cells. Blood 1996, 87, 4340-4347.

45. Baumgartner, B.; Weber, M.; Quirling, M.; Fischer, C.; Page, S.; Adam, M.; Von Schilling, C.; Waterhouse, C.; Schmid, C.; Neumeier, D.; Brand, K. Increased ikappab kinase activity is associated with activated nf-kappab in acute myeloid blasts. Leukemia 2002, 16, 2062-2071.

46. Kordes, U.; Krappmann, D.; Heissmeyer, V.; Ludwig, W.D.; Scheidereit, C. Transcription factor nf-kappab is constitutively activated in acute lymphoblastic leukemia cells. Leukemia 2000, 14, 399-402.

47. Chen, Z.J. Ubiquitin signalling in the nf-kappab pathway. Nat. Cell Biol. 2005, 7, 758-765.

48. Kohler, T.; Leiblein, S.; Borchert, S.; Eller, J.; Rost, A.K.; Lassner, D.; Krahl, R.; Helbig, W.; Wagner, O.; Remke, H. Absolute levels of mdr-1, mrp, and bcl-2 mrna and tumor remission in acute leukemia. Adv. Exp. Med. Biol. 1999, 457, 177-185. 
49. van der Kolk, D.M.; de Vries, E.G.; van Putten, W.J.; Verdonck, L.F.; Ossenkoppele, G.J.; Verhoef, G.E.; Vellenga, E. P-glycoprotein and multidrug resistance protein activities in relation to treatment outcome in acute myeloid leukemia. Clin. Cancer Res. 2000, 6, 3205-3214.

50. Matondo, M.; Bousquet-Dubouch, M.P.; Gallay, N.; Uttenweiler-Joseph, S.; Recher, C.; Payrastre, B.; Manenti, S.; Monsarrat, B.; Burlet-Schiltz, O. Proteasome inhibitor-induced apoptosis in acute myeloid leukemia: A correlation with the proteasome status. Leuk. Res. 2010, 34, 498-506.

51. Agathocleous, A.; Rohatiner, A.; Rule, S.; Hunter, H.; Kerr, J.P.; Neeson, S.M.; Matthews, J.; Strauss, S.; Montoto, S.; Johnson, P.; Radford, J.; Lister, A. Weekly versus twice weekly bortezomib given in conjunction with rituximab, in patients with recurrent follicular lymphoma, mantle cell lymphoma and waldenstrom macroglobulinaemia. Br. J. Haematol. 2010, 151, 346-353.

52. Aghajanian, C.; Soignet, S.; Dizon, D.S.; Pien, C.S.; Adams, J.; Elliott, P.J.; Sabbatini, P.; Miller, V.; Hensley, M.L.; Pezzulli, S.; Canales, C.; Daud, A.; Spriggs, D.R. A phase i trial of the novel proteasome inhibitor ps341 in advanced solid tumor malignancies. Clin. Cancer Res. 2002, 8, 2505-2511.

53. Erlichman, C.; Adjei, A.A.; Thomas, J.P.; Wilding, G.; Reid, J.M.; Sloan, J.A.; Atherton, P.; Hanson, L.J.; Alberti, D.; Kaufmann, S.H.; Elliott, P. A phase i trial of the proteasome inhibitor ps-341in patients with advanced cancer. Proc. Am. Soc. Clin. Oncol. 2001, 20, Abstr. 337.

54. Papandreou, C.N.; Daliani, D.D.; Nix, D.; Yang, H.; Madden, T.; Wang, X.; Pien, C.S.; Millikan, R.E.; Tu, S.M.; Pagliaro, L.; Kim, J.; Adams, J.; Elliott, P.; Esseltine, D.; Petrusich, A.; Dieringer, P.; Perez, C.; Logothetis, C.J. Phase i trial of the proteasome inhibitor bortezomib in patients with advanced solid tumors with observations in androgen-independent prostate cancer. J. Clin. Oncol. 2004, 22, 2108-2121.

55. Hamilton, A.L.; Eder, J.P.; Pavlick, A.C.; Clark, J.W.; Liebes, L.; Garcia-Carbonero, R.; Chachoua, A.; Ryan, D.P.; Soma, V.; Farrell, K.; Kinchla, N.; Boyden, J.; Yee, H.; ZeleniuchJacquotte, A.; Wright, J.; Elliott, P.; Adams, J.; Muggia, F.M. Proteasome inhibition with bortezomib (ps-341): A phase i study with pharmacodynamic end points using a day 1 and day 4 schedule in a 14-day cycle. J. Clin. Oncol. 2005, 23, 6107-6116.

56. Jenkins, C.; Hewamana, S.; Gilkes, A.; Neelakantan, S.; Crooks, P.; Mills, K.; Pepper, C.; Burnett, A. Nuclear factor-kappab as a potential therapeutic target for the novel cytotoxic agent lc-1 in acute myeloid leukaemia. Br. J. Haematol. 2008, 143, 661-671.

57. Swords, R.T.; Kelly, K.R.; Smith, P.G.; Garnsey, J.J.; Mahalingam, D.; Medina, E.; Oberheu, K.; Padmanabhan, S.; O'Dwyer, M.; Nawrocki, S.T.; Giles, F.J.; Carew, J.S. Inhibition of nedd8activating enzyme: A novel approach for the treatment of acute myeloid leukemia. Blood 2010, $115,3796-3800$.

(C) 2011 by the authors; licensee MDPI, Basel, Switzerland. This article is an open access article distributed under the terms and conditions of the Creative Commons Attribution license (http://creativecommons.org/licenses/by/3.0/). 